Supporting Information for:

\title{
Inducing Structural Diversity in Anionic Metal-Tetraoxolene Coordination Polymers Using Templating Methyl Viologen Countercations
}

Martin P. van Koeverden ${ }^{\dagger}$, Brendan F. Abrahams ${ }^{*}$, Carol Hua ${ }^{\ddagger}$, Timothy A. Hudson, Richard Robson

School of Chemistry, The University of Melbourne, Parkville, Victoria 3010, Australia

$\uparrow$ Present Address: School of Chemistry, The University of Sydney, Sydney, NSW 2006, Australia.

+ Present Address: School of Life and Environmental Sciences, Deakin University, Waurn Ponds, VIC 3216, Australia

*Email: bfa@unimelb.edu.au

\section{Table of Contents}

Experimental

Additional Details of Crystal Structure Refinement $\quad$ S6

Table S1 Crystallographic data for the 3D dia networks $\mathbf{1}_{\mathrm{Mn}}$ and $\mathbf{1}_{\mathbf{C d}} \quad$ S8

Figure S1 P-XRD $(\lambda=1.54184 \AA)$ pattern of $\mathbf{1}_{\mathrm{Mn}} \quad$ S9

Figure S2 P-XRD $(\lambda=1.54184 \AA)$ pattern of $\mathbf{1 C d}_{\mathrm{Cd}} \quad \mathrm{S} 10$

Figure S3 ATR FT-IR spectra of $\mathbf{1}_{\mathbf{M n}}$ and $\mathbf{1}_{\mathbf{C d}} \quad$ S11

Figure S4 Thermogravimetric analyses of $\mathbf{1}_{\mathbf{M n}}$ and $\mathbf{1}_{\mathbf{C d}} \quad \mathrm{S} 12$

Table S2 Analysis of the possible metal coordination geometries in $\mathbf{1}_{\mathbf{M n}}$ and $\mathbf{1}_{\mathbf{C d}} \quad$ S13

Estimation of $\mathbf{M e V}^{m+}$ Valence State $\quad$ S14

Figure S5 Diagnostic bond lengths in $\mathrm{MeV}^{m+}$ species for estimation of $\begin{array}{lr}\text { oxidation state } & \text { S14 }\end{array}$

Table S3 Diagnostic mean bond lengths in $\mathrm{MeV}^{0}, \mathrm{MeV}^{+\bullet}$ and $\mathrm{MeV}^{2+}$ species reported in literature for calculation of Kistenmacher relationship parameters $\quad$ S14

Figure S6 Bond lengths in $\mathrm{MeV}^{m+}$ moieties (a) $\left(\mathrm{MeV} \mathrm{PF}_{6}\right.$, (b) $\mathrm{MeV}\left(\mathrm{PF}_{6}\right)_{2}$, (c) $\mathbf{1}_{\mathbf{M n}}$, (d) $\mathbf{1}_{\mathbf{C d}}$, (e) 2a, (f) 3Mn and (g) 3 $\mathbf{C d} \quad \mathrm{S} 15$

Table S4 Summary of the mean diagnostic bond lengths and estimated charge $(q)$ for $\mathrm{MeV}^{m+}$ moieties in coordination polymers in this work $\mathrm{S} 16$

Figure S7 Interactions between $\mathrm{MeV}^{2+}$ cations (purple) and the anionic $\left[\mathrm{Mn}(\mathrm{Clan})_{2}\right]^{2-}$ $\begin{array}{ll}\text { adamantane unit }(\tan ) \text { in } \mathbf{1}_{\mathbf{M n}} & \text { S17 }\end{array}$

Table S5 Crystallographic data for the 2D honeycomb network 2a S18

Figure S8 P-XRD $(\lambda=1.54184 \AA)$ pattern of a MeCN slurry of 2a $\quad$ S19

Figure S9 Interactions between $\mathrm{MeV}^{2+}$ cations and anionic $\left[\mathrm{Mn}_{2}(\mathrm{Clan})_{3}\right]^{2-}$ $\begin{array}{ll}\text { sheets in } \mathbf{2 a} & \text { S20 }\end{array}$ 
Figure S10 Synchrotron P-XRD $(\lambda=0.58835 \AA$ ) pattern of bulk $2 \mathbf{b}$ (isolated 2a) $\quad$ S21

Figure S11 (a) ATR FT-IR spectrum and (b) thermogravimetric analysis of $\mathbf{2 b} \quad$ S22

Table S6 Crystallographic data for the 1D coordination polymers $\mathbf{3}_{\mathbf{M n}}, \mathbf{3}_{\mathbf{C d}}$ and $\mathbf{4}_{\mathbf{C d}} \quad \mathrm{S} 23$

$\begin{array}{lll}\text { Figure S12 } & \text { ATR FT-IR spectra of } \mathbf{3}_{\mathrm{Mn}} \text { and } \mathbf{3}_{\mathbf{C d}} & \text { S24 }\end{array}$

Figure S13 P-XRD $(\lambda=1.54184 \AA)$ pattern of $\mathbf{3}_{\mathrm{Mn}} \quad \mathrm{S} 25$

Figure S14 P-XRD $(\lambda=1.54184 \AA)$ pattern of $\mathbf{3}$ Cd $\quad$ S26

Figure S15 The structure of $\left[\mathrm{Cd}(\mathrm{Fan})\left(\mathrm{H}_{2} \mathrm{O}\right)_{2}\right]\left(\mathbf{4}_{\mathrm{Cd}}\right)$ 1D strip coordination polymer $\quad \mathrm{S} 27$

Table S7 Atomic separations and angles involving selected close contacts between $\mathrm{C}-\mathrm{H}$ units of $\mathrm{MeV}^{2+}$ cations with $\mathrm{Clan}^{2-}$ and $\mathrm{Fan}^{2-}$ ligands within $\mathbf{1}_{\mathbf{M n}}, \mathbf{1}_{\mathbf{C d}}, \mathbf{2 a}, \mathbf{3}_{\mathbf{M n}}$ and $\mathbf{3} \mathbf{C d}$. $\quad$ S28

References 


\section{Experimental}

\section{General Considerations}

Anhydrous $\mathrm{MeCN}$ was obtained by drying $\mathrm{MeCN}$ twice sequentially over activated $3 \AA$ molecular sieves, which was then stored under an atmosphere of dry $\mathrm{N}_{2}$. Proton $\left({ }^{1} \mathrm{H}\right)$ and proton-decoupled carbon-13 $\left({ }^{13} \mathrm{C}\left\{{ }^{1} \mathrm{H}\right\}\right)$ NMR spectroscopy was performed using a Varian Unity spectrometer operating at 400 and $100 \mathrm{MHz}$ respectively. All spectra were acquired at $25{ }^{\circ} \mathrm{C}$. Proton $\left(\delta_{\mathrm{H}}\right)$ and carbon-13 $\left(\delta_{\mathrm{C}}\right)$ chemical shift values are reported in parts per million (ppm) downfield of external tetramethylsilane. ${ }^{1} \mathrm{H}$ - and ${ }^{13} \mathrm{C}\left\{{ }^{1} \mathrm{H}\right\}$-NMR spectra were referenced to residual ${ }^{1} \mathrm{H}$ signals in the deuterated solvents and the solvent signal respectively, except for spectra acquired in $\mathrm{D}_{2} \mathrm{O}$ which were referenced to the ${ }^{1} \mathrm{H}$ and ${ }^{13} \mathrm{C}$ signals of acetone (internal standard, $\left.\delta_{\mathrm{H}} 2.22 ; \delta_{\mathrm{C}} 215.94\right)$. Thermogravimetric analysis (TGA) was performed using a Mettler Toledo TGA/SDTA851e between $25^{\circ} \mathrm{C}$ and $450{ }^{\circ} \mathrm{C}$ using a heating rate of $5{ }^{\circ} \mathrm{C} \mathrm{min}{ }^{-1}$ in a flow of $\mathrm{N}_{2}$. Fourier-transform infrared (FT-IR) spectra were recorded in air under ambient conditions using either a Bruker Tensor 27 FTIR spectrometer ( $\mathrm{KBr}$ discs), or a Perkin Elmer Spotlight 100 spectrometer fitted with a ZnSe Universal ATR accessory. Elemental analyses $(\mathrm{CHN})$ were performed at the Campbell Microanalytical Laboratory, University of Otago.

\section{3,6-Difluoro-2,5-dihydroxy-1,4-benzoquinone (Fluoranilic acid, $\mathrm{H}_{2}$ Fan)}

$\mathrm{H}_{2}$ Fan was synthesised using a modified literature procedure ${ }^{1}$ in two steps from commercially available 2,3,5,6-tetrafluorohydroquinone, via the intermediate 2,3,5,6-tetrafluoro-1,4benzoquinone $\left(\mathrm{F}_{4} \mathrm{BQ}\right)$, also obtained using a modified literature procedure. ${ }^{2}$ In brief, $\left(\mathrm{NH}_{4}\right)_{2} \mathrm{Ce}^{\mathrm{IV}}\left(\mathrm{NO}_{3}\right)_{6}(145.1 \mathrm{~g}, 220 \mathrm{mmol})$ was dissolved with stirring in $\mathrm{H}_{2} \mathrm{O}(700 \mathrm{~mL}) .2,3,5,6-$ Tetrafluorohydroquinone $(18.21 \mathrm{~g}, 100 \mathrm{mmol})$ was added portion wise to the stirring $\mathrm{Ce}^{\mathrm{IV}}$ solution, causing an immediate colour change from a transparent orange solution to a paleyellow suspension. The reaction was stirred $1 \mathrm{hr}$ at rt., then extracted with $\mathrm{Et}_{2} \mathrm{O}(3 \times 200 \mathrm{~mL})$ until the organic extract was colourless. The combined organic phase was washed with $\mathrm{H}_{2} \mathrm{O}$ acidified with 2 drops conc. $\mathrm{HCl}(2 \times 150 \mathrm{~mL})$, brine acidified with 1 drop conc. $\mathrm{HCl}(150$ $\mathrm{mL}$ ), dried over $\mathrm{MgSO}_{4}$ then concentrated to dryness at reduced pressure, yielding $\mathrm{F}_{4} \mathrm{BQ}$ as a pale yellow scaly solid (15.63 g, 86.8\%), which was used without further purification. FT-IR (KBr, cm ${ }^{-1}$ ): 3442 (br s), 1702 (s), 1690 (s), 1677 (s), 1384 (m), 1335 (m), 1266 (w), 1004 (m), 542 (br w).

$\mathrm{NaOH}$ (9.5582 g, $734 \mathrm{mmol})$ was dissolved in $\mathrm{H}_{2} \mathrm{O}(190 \mathrm{~mL})$ and cooled in an ice-water bath to $<10{ }^{\circ} \mathrm{C} . \mathrm{F}_{4} \mathrm{BQ}(9.5582 \mathrm{~g}, 53.1 \mathrm{mmol})$ dissolved in 1,4-dioxane $(75 \mathrm{~mL})$ was added dropwise over $30 \mathrm{~min}$ to the vigorously stirring $\mathrm{NaOH}$ solution. The reaction was then stirred $30 \mathrm{~min}$ at $10{ }^{\circ} \mathrm{C}$, then warmed to $60{ }^{\circ} \mathrm{C}$ and stirred $1 \mathrm{hr}$. The chocolate brown suspension was cooled to rt., then the solids isolated by suction filtration (Por. 3 frit). The product was washed on the frit with $10 \%$ w/w $\mathrm{NaOH}$ solution $(2 \times 75 \mathrm{~mL}), 1: 1 \mathrm{v} / \mathrm{v} \mathrm{EtOH} / \mathrm{H}_{2} \mathrm{O}(100 \mathrm{~mL})$ then $\mathrm{EtOH}(100 \mathrm{~mL})$. The chocolate brown solid was then dried $24 \mathrm{hrs}$ at $100{ }^{\circ} \mathrm{C}$ yielding an olive-green crude of $\mathrm{Na}_{2} \mathrm{Fan}(10.51 \mathrm{~g})$. The crude $\mathrm{Na}_{2}$ Fan $(10.51 \mathrm{~g})$ was suspended in $\mathrm{H}_{2} \mathrm{O}(300 \mathrm{~mL})$ and heated to $60{ }^{\circ} \mathrm{C}$ with stirring. Conc. $\mathrm{HCl}(100 \mathrm{~mL})$ was added dropwise to the stirring suspension, causing precipitation of a dark red crystalline product. The reaction was cooled to rt., then the precipitated solids isolated by suction filtration (Por. 3 frit), then dried by suction yielding an orange-red crude $(6.4468 \mathrm{~g})$. The crude was dissolved in the minimum of boiling $\mathrm{AcOH}$ 
$(120 \mathrm{~mL})$, hot filtered to remove trace brown residue, then concentrated by boiling to ca. 80 $\mathrm{mL}$. The intense cherry-red solution was then cooled slowly to rt. The crystallised orange-red rods were isolated by suction filtration (Por. 3 frit), dried by suction then washed with $n$-hexane $(2 \times 100 \mathrm{~mL})$, then dried in vacuo $\left(0.3 \mathrm{mbar}, 80^{\circ} \mathrm{C}\right)$ over $\mathrm{KOH}$ yielding the title compound as a bright orange powder $\left(4.88 \mathrm{~g}, 52.2 \%\right.$ from $\left.\mathrm{F}_{4} \mathrm{BQ}\right)$. FT-IR $\left(\mathrm{KBr}, \mathrm{cm}^{-1}\right): 3585$ (br s), 3477 (br s), 1673 (m), 1631 (s), 1452 (w), 1384 (w), 1303 (m), 998 (m), 606 (br w).

\section{3,6-Difluoro-1,2,4,5-tetrahydroxybenzene ( $\mathrm{H}_{4}$ Fan)}

3,6-Difluoro-1,2,4,5-tetrahydroxybenzene $\left(\mathrm{H}_{4} \mathrm{Fan}\right)$ was synthesised according to a modified literature procedure. ${ }^{3}$ In air, $\mathrm{H}_{2} \mathrm{Fan}(4.2420 \mathrm{~g}, 24.1 \mathrm{mmol})$ was suspended in conc. $\mathrm{HCl}$ (100 $\mathrm{mL}$ ) then heated to $100{ }^{\circ} \mathrm{C}$ with stirring. Mossy tin (3.433 g, $28.9 \mathrm{mg}$-atom) was added portion wise over 5 minutes to the stirring orange-red suspension, causing gas evolution and gradual bleaching of the solution. After $30 \mathrm{~min}$., the clear pale-yellow solution was hot filtered through glass fibre paper to remove traces of insoluble tan residue and unreacted $\mathrm{Sn}$. The clear filtrate was cooled slowly to rt., then $4{ }^{\circ} \mathrm{C}$ overnight. The crystallised pale-tan needles were isolated by suction filtration (Por. 3 frit) under an $\mathrm{N}_{2}$ stream, then washed on the frit with conc. $\mathrm{HCl}$ (2 $\times 30 \mathrm{~mL}$ ), dried by suction in a brisk $\mathrm{N}_{2}$ stream, then washed on the frit with ice-cold $\mathrm{CHCl}_{3}$ $(2 \times 30 \mathrm{~mL})$. The product was then dried in vacuo over $\mathrm{KOH}$ then $\mathrm{P}_{2} \mathrm{O}_{5}$, yielding the title compound as pale-tan needles $(3.77 \mathrm{~g}, 87.9 \%)$. The product is stable over several months when stored under $\mathrm{N}_{2}$ at $4{ }^{\circ} \mathrm{C}$. FT-IR (ATR, $\mathrm{cm}^{-1}$ ): 3525 (br m), 3373 (br m), 3211 (br m), 1648 (m), 1546 (w), 1532 (w), 1498 (s), 1405 (w), 1327 (m), 1294 (w), 1235 (w), 1207 (m), 988 (m), 955 (s), $703(\mathrm{w}), 635(\mathrm{w}), 608(\mathrm{w})$.

\section{3,6-Dichloro-1,2,4,5-tetrahydroxybenzene ( $\left.\mathrm{H}_{4} \mathrm{Clan}\right)$}

$\mathrm{H}_{4}$ Clan was synthesised using a modified literature procedure. ${ }^{3} \mathrm{In}$ air, chloranilic acid $\left(\mathrm{H}_{2} \mathrm{Clan}\right.$, $6.270 \mathrm{~g}, 30 \mathrm{mmol})$ was suspended in concentrated $\mathrm{HCl}(150 \mathrm{~mL})$ then heated to $100{ }^{\circ} \mathrm{C}$ with stirring. Mossy tin (4.271 g, $36 \mathrm{mg}$-atom) was added portion wise over 5 minutes to the stirring red-orange suspension, causing gas evolution, and gradual bleaching of the solution. After 20 min., the clear pale-yellow reaction solution was hot filtered through glass fibre paper to remove traces of an insoluble tan residue and unreacted Sn, rinsing the reaction flask with additional hot concentrated $\mathrm{HCl}(2 \times 20 \mathrm{~mL})$. The clear filtrate was transferred to a flask fitted with a septum, purged with $\mathrm{N}_{2}$ then cooled to rt. then $4{ }^{\circ} \mathrm{C}$ overnight. The product crystallised as white needles, which were isolated by suction filtration. The product was washed with icecold concentrated $\mathrm{HCl}(3 \times 25 \mathrm{~mL})$, then sucked dry and washed with ice-cold $\mathrm{CHCl}_{3}(2 \times 25$ $\mathrm{mL}$ ). The solid was dried in vacuo over $\mathrm{KOH}$ then $\mathrm{P}_{2} \mathrm{O}_{5}$, yielding the title compound as white to pale-tan needles $(3.8505 \mathrm{~g}, 61.1 \%)$. The product is stable over several months when stored under dry $\mathrm{N}_{2}$ at $4{ }^{\circ} \mathrm{C} .{ }^{13} \mathrm{C}\left\{{ }^{1} \mathrm{H}\right\}$-NMR $\left(100 \mathrm{MHz}, d_{6}\right.$-Acetone): $\delta_{\mathrm{C}} 137.3,110.5$. FT-IR (ATR, cm ${ }^{-1}$ ): 3281 (s, br); 1632 (w); 1541 (w); 1466 (s); 1327 (m); 1288 (m); 1148 (s); 961 (s); $920(\mathrm{~m}) ; 861(\mathrm{~m}) ; 821$ (s); $713(\mathrm{~m}) ; 608$ (m).

\section{$N, N^{\prime}$-Dimethyl-4,4'-bipyridinium di(4-toluenesulfonate) [MeV(OTs) 2 ]}

4,4'-Bipyridine (4,4'-bpy, $9.371 \mathrm{~g}, 60 \mathrm{mmol})$ and methyl-4-toluenesulfonate $(27.00 \mathrm{~g}, 145$ $\mathrm{mmol}$ ) were added to an oven-dried $500 \mathrm{~mL}$ round-bottom flask fitted with a reflux condenser topped with a $\mathrm{CaCl}_{2}$ guard tube. Anhydrous $\mathrm{MeCN}(350 \mathrm{~mL})$ was added, then the reaction placed in a thermostated oil bath $\left(90{ }^{\circ} \mathrm{C}\right)$ and stirred $12 \mathrm{hrs}$. The pale-yellow reaction 
suspension was then cooled to rt., and the precipitated pale-yellow solid isolated by suction filtration (Por. 3 frit), rinsing the reaction flask with additional $\mathrm{MeCN}(2 \times 50 \mathrm{~mL})$. The product was washed on the frit with acetone $(2 \times 200 \mathrm{~mL})$ then $\mathrm{Et}_{2} \mathrm{O}(100 \mathrm{~mL})$, then dried in vacuo over $\mathrm{P}_{2} \mathrm{O}_{5}$, yielding the title compound as a pale-yellow powder $(26.6 \mathrm{~g}, 83.9 \%)$. ${ }^{1} \mathrm{H}-\mathrm{NMR}(400$ $\left.\mathrm{MHz}, \mathrm{D}_{2} \mathrm{O}\right): \delta_{\mathrm{H}} 8.98\left(\mathrm{~d}, J_{\mathrm{AB}}=6.7 \mathrm{~Hz}, 4 \mathrm{H}, \mathrm{Py}^{+}-\boldsymbol{H} 2,2^{\prime}, 6,6^{\prime}\right), 8.42\left(\mathrm{~d}, J_{\mathrm{AB}}=6.7 \mathrm{~Hz}, 4 \mathrm{H}, \mathrm{Py}^{+}-\right.$ $\left.\boldsymbol{H} 3,3^{\prime}, 5,5^{\prime}\right), 7.61\left(\mathrm{~d}, J_{\mathrm{AB}}=8.1 \mathrm{~Hz}, 4 \mathrm{H}, \operatorname{Ar}-\boldsymbol{H} 2,6\right), 7.30\left(\mathrm{~d}, J_{\mathrm{AB}}=8.1 \mathrm{~Hz}, 4 \mathrm{H}, \operatorname{Ar}-\boldsymbol{H} 3,5\right), 4.46(\mathrm{~s}$, $\left.6 \mathrm{H}, \mathrm{N}^{+}-\mathrm{CH}_{3}\right), 2.35$ (s, 6H, Ar-CH H $_{3}$. FT-IR $\left(\mathrm{KBr}, \mathrm{cm}^{-1}\right.$ ): 3443 (br m), 3052 (m), 1642 (m), 1567 (w), 1511 (w), 1452 (w), 1358 (w), 1177 (s), 1119 (s), 1030 (m), 1006 (m), 835 (m), 820 (m), $683(\mathrm{~s}), 567(\mathrm{~s}), 474(\mathrm{w})$. 


\section{Additional Details of Crystal Structure Refinement}

$(\mathrm{MeV})\left[\mathrm{Mn}(\mathrm{Clan})_{2}\right]\left(\mathbf{1}_{\mathrm{Mn}}\right)$ and $(\mathrm{MeV})\left[\mathrm{Cd}(\mathrm{Clan})_{2}\right]\left(\mathbf{1}_{\mathrm{Cd}}\right)$

Crystallographic data were measured at $100 \mathrm{~K}\left(\mathbf{1}_{\mathbf{M n}}\right)$ or $120 \mathrm{~K}\left(\mathbf{1}_{\mathbf{C d}}\right)$ using a Rigaku XtaLAB Synergy-S diffractometer (Table S1). For both $\mathbf{1}_{\mathbf{M n}}$ and $\mathbf{1}_{\mathbf{C d}}$, data beyond $d=0.8 \AA$ were excluded from the refinement using the SHEL instructions. In $\mathbf{1}_{\mathbf{M n}}$, rigid bond restraints were applied to non-hydrogen atoms (excluding $\mathrm{Mn}$ ) in the structure using the RIGU instruction.

\section{$(\mathrm{MeV})\left[\mathrm{Mn}_{2}(\mathrm{Clan})_{3}\right] \cdot 6 \mathrm{MeCN}(2 \mathrm{a})$}

Crystallographic data for $\mathbf{2 a}$ were measured at $100 \mathrm{~K}$ (Table S5) using a Rigaku XtaLAB Synergy-S diffractometer. Rigid bond restraints were applied to all non-hydrogen atoms (excluding Mn) in the structure using the RIGU instruction.

$(\mathrm{MeV})\left[\mathrm{Mn}_{2}(\operatorname{Fan})_{3}\left(\mathrm{H}_{2} \mathrm{O}\right)_{2}\right] \cdot 2 \mathrm{MeCN} \cdot 0.5 \mathrm{H}_{2} \mathrm{O}\left(3_{\mathrm{Mn}}\right) \&$ $(\mathrm{MeV})\left[\mathrm{Cd}_{2}(\mathrm{Fan})_{3}\left(\mathrm{H}_{2} \mathrm{O}\right)_{2}\right] \cdot 2 \mathrm{MeCN} \cdot 0.6 \mathrm{H}_{2} \mathrm{O}\left(3_{\mathrm{Cd}}\right)$

Crystallographic data for $\mathbf{3}_{\mathrm{Mn}}$ and $\mathbf{3} \mathrm{Cd}$ were measured at $100 \mathrm{~K}$ using Rigaku XtaLAB Synergy$\mathrm{S}$ diffractometer (Table S6). For both $\mathbf{3}_{\mathbf{M n}}$ and $\mathbf{3} \mathbf{C d}$, rigid bond restraints were applied to all nonhydrogen atoms in the $\mathrm{MeV}^{2+}$ cations using the RIGU instruction; in $\mathbf{3}_{\mathbf{C d}}$, similar distance restraints were also applied to all non-hydrogen atoms of the $\mathrm{MeV}^{2+}$ cations using the SIMU instruction. For the coordinated $\mathrm{H}_{2} \mathrm{O}$ molecules in $\mathbf{3}_{\mathbf{M n}}$ and $\mathbf{3} \mathbf{C d}$, the $\mathrm{H}$ atom positions were determined by examining the $F_{C}-F_{O}$ map, with interatomic distance restraints of $0.84 \AA(\mathrm{O}-\mathrm{H}$ 1,2 distance) and $1.34 \AA$ ( $\mathrm{H} \cdots \mathrm{H} 1,3$ distance $)$ applied using the DFIX instruction.

In $\mathbf{3}_{\mathrm{Mn}}$, rigid bond and similar distance restraints were applied to the well-ordered $\mathrm{MeCN}$ molecule contained in the network void formed by the $\mathrm{Mn}_{4}$ parallelogram, using the RIGU and SIMU instructions. Modelling of the remaining solvent was attempted, but the disorder was too severe to give a satisfactory solvent model. The scattering contribution of this disordered solvent was therefore accounted for using the SQUEEZE ${ }^{4}$ routine of PLATON. ${ }^{5}$ The content of disordered solvent in the compound was estimated from the electron count estimated by SQUEEZE as one $\mathrm{MeCN}$ and $0.5 \mathrm{H}_{2} \mathrm{O}$ per formula unit. The total estimated solvation is therefore $(\mathrm{MeV})\left[\mathrm{Mn}_{2}(\operatorname{Fan})_{3}\left(\mathrm{H}_{2} \mathrm{O}\right)_{2}\right] \cdot(1+1) \mathrm{MeCN} \cdot 0.5 \mathrm{H}_{2} \mathrm{O}$

i.e. $(\mathrm{MeV})\left[\mathrm{Mn}_{2}(\mathrm{Fan})_{3}\left(\mathrm{H}_{2} \mathrm{O}\right)_{2}\right] \cdot 2 \mathrm{MeCN} \cdot 0.5 \mathrm{H}_{2} \mathrm{O}$. The slight discrepancy between solvation estimated by SC-XRD and that calculated by TGA and elemental analysis is due to partial solvent loss upon isolation of $\mathbf{3} \mathbf{M n}$.

In $\mathbf{3}$ Cd, additional restraints were necessary for the solvent model. The thermal ellipsoids the $\mathrm{MeCN}$ molecule residing in the network void formed by the $\mathrm{Cd}_{4}$ parallelogram, were unacceptably large when modelled at a single position. This solvent was therefore modelled as disordered over two positions, with the total occupancy fixed at one, and the occupancy of each site allowed to refine against each other. The thermal displacement parameters of equivalent atoms at the two positions were constrained to be equal using the EADP instruction. Rigid bond and similar distance restraints were applied to all non-hydrogen atoms in $\mathrm{MeCN}$ using the RIGU and SIMU instructions. Additional interatomic distance restraints of $1.137 \AA$ ( $\mathrm{C} \equiv \mathrm{N} 1,2$ distance $), 1.456 \AA$ (C- $\mathrm{CH}_{3} 1,2$ distance $)$ and $2.593 \AA\left(\mathrm{N} \cdots \mathrm{CH}_{3} 1,3\right.$ distance $)$ were applied using the DFIX instruction for all MeCN molecules. Modelling of the remaining residual electron density attributed to solvent was attempted, but the disorder was too severe to give a satisfactory structure refinement. The scattering contribution of the disordered solvent was 
therefore accounted for using the SQUEEZE ${ }^{4}$ routine of PLATON. ${ }^{5}$ The content of disordered solvent in the compound was estimated from the electron count estimated by SQUEEZE as one $\mathrm{MeCN}$ and $0.6 \mathrm{H}_{2} \mathrm{O}$ per formula unit. The total estimated solvation is therefore $(\mathrm{MeV})\left[\mathrm{Cd}_{2}(\mathrm{Fan})_{3}\left(\mathrm{H}_{2} \mathrm{O}\right)_{2}\right] \cdot(1+1) \mathrm{MeCN} \cdot 0.6 \mathrm{H}_{2} \mathrm{O}$ i.e. $(\mathrm{MeV})\left[\mathrm{Cd}_{2}(\mathrm{Fan})_{3}\left(\mathrm{H}_{2} \mathrm{O}\right)_{2}\right] \cdot 2 \mathrm{MeCN} \cdot 0.6 \mathrm{H}_{2} \mathrm{O}$.

\section{$\left[\mathrm{Cd}(\mathrm{Fan})\left(\mathrm{H}_{2} \mathrm{O}\right)_{2}\right]\left(4_{\mathrm{Cd}}\right)$}

Crystallographic data for $\mathbf{4}_{\mathrm{Cd}}$ were collected at $100 \mathrm{~K}$ using the MX2 beamline of the Australian Synchrotron at $\lambda=0.71073 \AA$ (Table S6), achieved using a single $\varphi$ scan $\left(\varphi=0-360^{\circ}, \kappa=0^{\circ}\right.$, $\omega=0^{\circ}$ ), with frames collected every $0.1^{\circ}$ in $\varphi .^{6}$ Unit cell indexing and refinement, data reduction and absorption corrections were performed using XDS. ${ }^{7}$ For the coordinated $\mathrm{H}_{2} \mathrm{O}$ molecules, the $\mathrm{H}$ atom positions were determined by examining the $F_{\mathrm{C}}-F_{\mathrm{O}}$ map with interatomic distance restraints of $0.84 \AA$ (O-H 1,2 distance) and $1.34 \AA$ ( $\mathrm{H} \cdots \mathrm{H} 1,3$ distance) applied using the DFIX instruction. The data completeness to $\theta$ is low (87.6\%) due to the low triclinic symmetry of $\mathbf{4}_{\mathbf{C d}}$ and because the MX2 beamline only allows crystal rotation about one axis $(\varphi)$. 
Table S1. Crystallographic data for the 3D dia networks $\mathbf{1}_{\mathbf{M n}}$ and $\mathbf{1}_{\mathbf{C d}}$.

\begin{tabular}{|c|c|c|}
\hline Compound & $(\mathrm{MeV})\left[\mathrm{Mn}(\mathrm{Clan})_{2}\right]\left(\mathbf{1}_{\mathbf{M n}}\right)$ & $(\mathrm{MeV})\left[\mathrm{Cd}(\mathrm{Clan})_{2}\right](\mathbf{1} \mathbf{C d})$ \\
\hline Empirical formula & $\mathrm{C}_{24} \mathrm{H}_{14} \mathrm{~N}_{2} \mathrm{O}_{8} \mathrm{Cl}_{4} \mathrm{Mn}$ & $\mathrm{C}_{24} \mathrm{H}_{14} \mathrm{~N}_{2} \mathrm{O}_{8} \mathrm{Cl}_{4} \mathrm{Cd}$ \\
\hline Formula weight & 655.11 & 712.57 \\
\hline Habit & Octahedron & Irregular \\
\hline$T / \mathrm{K}$ & $99.9(4)$ & $121(2)$ \\
\hline Crystal system & Orthorhombic & Orthorhomic \\
\hline Space group & $F d d d$ & Fddd \\
\hline$a / \AA$ & $10.06100(10)$ & $10.0460(2)$ \\
\hline$b / \AA$ & $18.0409(2)$ & $18.1043(2)$ \\
\hline$c / \AA$ & $26.2770(3)$ & $26.7761(4)$ \\
\hline$\alpha /^{\circ}$ & 90 & 90 \\
\hline$\beta 1^{\circ}$ & 90 & 90 \\
\hline$\gamma /{ }^{\circ}$ & 90 & 90 \\
\hline$V / \AA^{3}$ & $4769.53(9)$ & $4869.92(13)$ \\
\hline$Z$ & 8 & 8 \\
\hline$\rho_{\text {calc }} / \mathrm{g} \mathrm{cm}^{-3}$ & 1.825 & 1.944 \\
\hline$\mu / \mathrm{mm}^{-1}$ & 9.142 & 11.730 \\
\hline$F_{000}$ & 2632.0 & 2816.0 \\
\hline Crystal size $/ \mathrm{mm}^{3}$ & $0.269 \times 0.202 \times 0.056$ & $0.159 \times 0.07 \times 0.054$ \\
\hline Radiation & $\mathrm{Cu} \mathrm{K} \alpha(\lambda=1.54184 \AA)$ & $\mathrm{Cu} \mathrm{K} \alpha(\lambda=1.54184 \AA)$ \\
\hline $2 \theta$ range $/^{\circ}$ & 10.616 to 149.004 & 10.6 to 148.808 \\
\hline Index ranges & $\begin{array}{l}-12 \leq h \leq 11 \\
-22 \leq k \leq 19 \\
-32 \leq l \leq 17\end{array}$ & $\begin{array}{l}-12 \leq h \leq 12 \\
-22 \leq k \leq 16 \\
-32 \leq l \leq 33\end{array}$ \\
\hline $\begin{array}{l}\text { Total/independent } \\
\text { reflections }\end{array}$ & $\begin{array}{l}5125 / 1210 \\
{\left[R_{\text {int }}=0.0268\right.} \\
\left.R_{\text {sigma }}=0.0164\right]\end{array}$ & $\begin{array}{l}6587 / 1242 \\
{\left[R_{\text {int }}=0.0307,\right.} \\
\left.R_{\text {sigma }}=0.0189\right]\end{array}$ \\
\hline $\begin{array}{l}\text { Data/restraints/ } \\
\text { parameters }\end{array}$ & $1210 / 48 / 92$ & $1242 / 0 / 92$ \\
\hline $\begin{array}{l}\text { Goodness-of-fit on } \\
F^{2}\end{array}$ & 1.083 & 1.085 \\
\hline $\begin{array}{l}\text { Final } R \text { indexes } \\
{[I \geq 2 \sigma(I)]}\end{array}$ & $\begin{array}{l}R_{1}=0.0301, \\
w R_{2}=0.0853\end{array}$ & $\begin{array}{l}R_{1}=0.0244 \\
w R_{2}=0.0659\end{array}$ \\
\hline $\begin{array}{l}\text { Final } R \text { indexes } \\
\text { [all data] }\end{array}$ & $\begin{array}{l}R_{1}=0.0305 \\
w R_{2}=0.0856\end{array}$ & $\begin{array}{l}R_{1}=0.0249 \\
w R_{2}=0.0663\end{array}$ \\
\hline $\begin{array}{l}\text { Largest diff. } \\
\text { peak/hole/ e } \AA^{-3}\end{array}$ & $0.35 /-0.35$ & $0.52 /-0.58$ \\
\hline
\end{tabular}




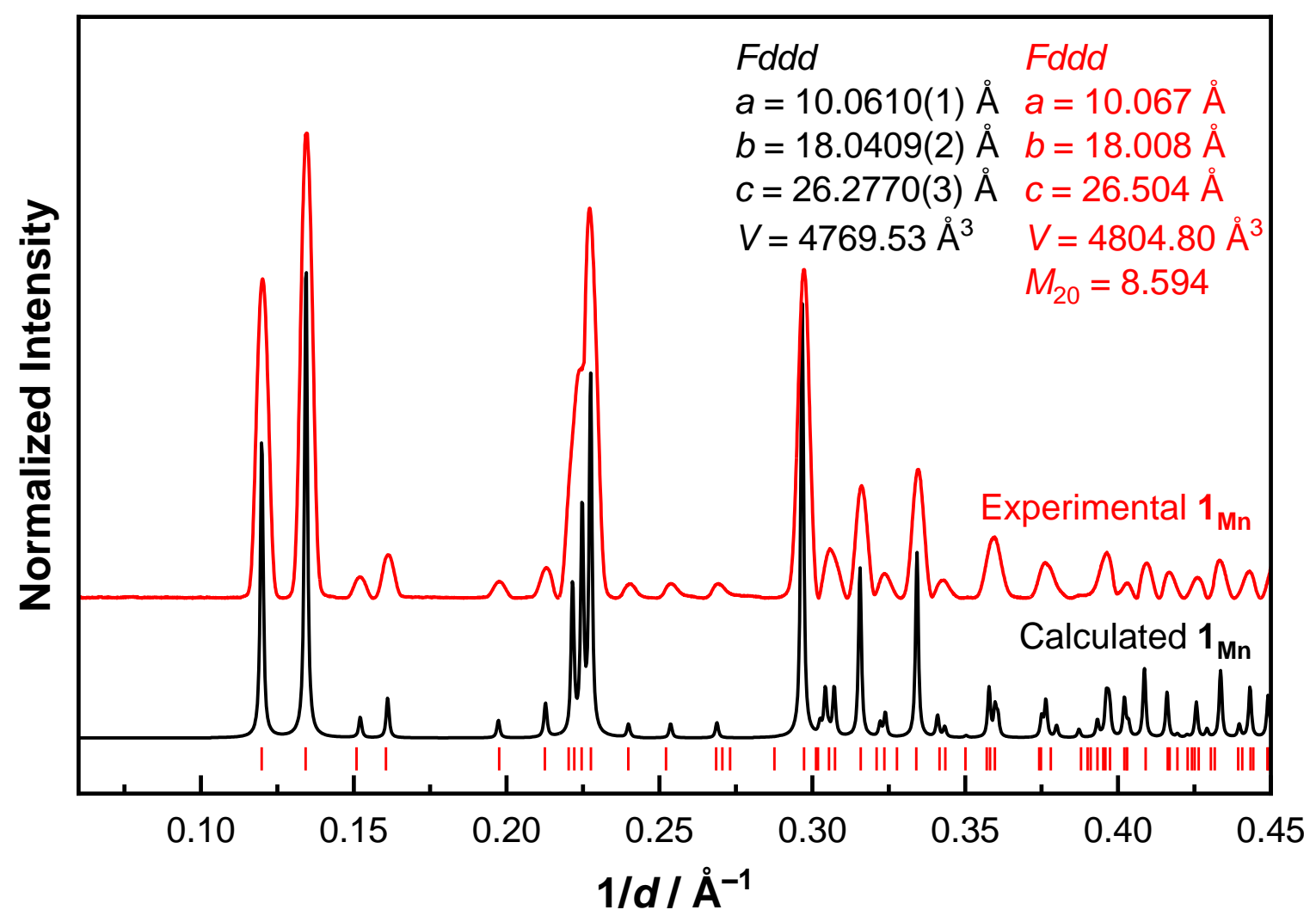

Figure S1. P-XRD $\left(\lambda=1.54184 \AA\right.$ ) pattern of $\mathbf{1}_{\mathrm{Mn}}(\mathrm{red}, T=100 \mathrm{~K})$ and calculated pattern from SC-XRD of $\mathbf{1}_{\mathrm{Mn}}$ (black, $T=100 \mathrm{~K}$ ). Tick marks (red) indicate the positions of the allowed reflections for the unit cell indexed from the experimental P-XRD pattern. 


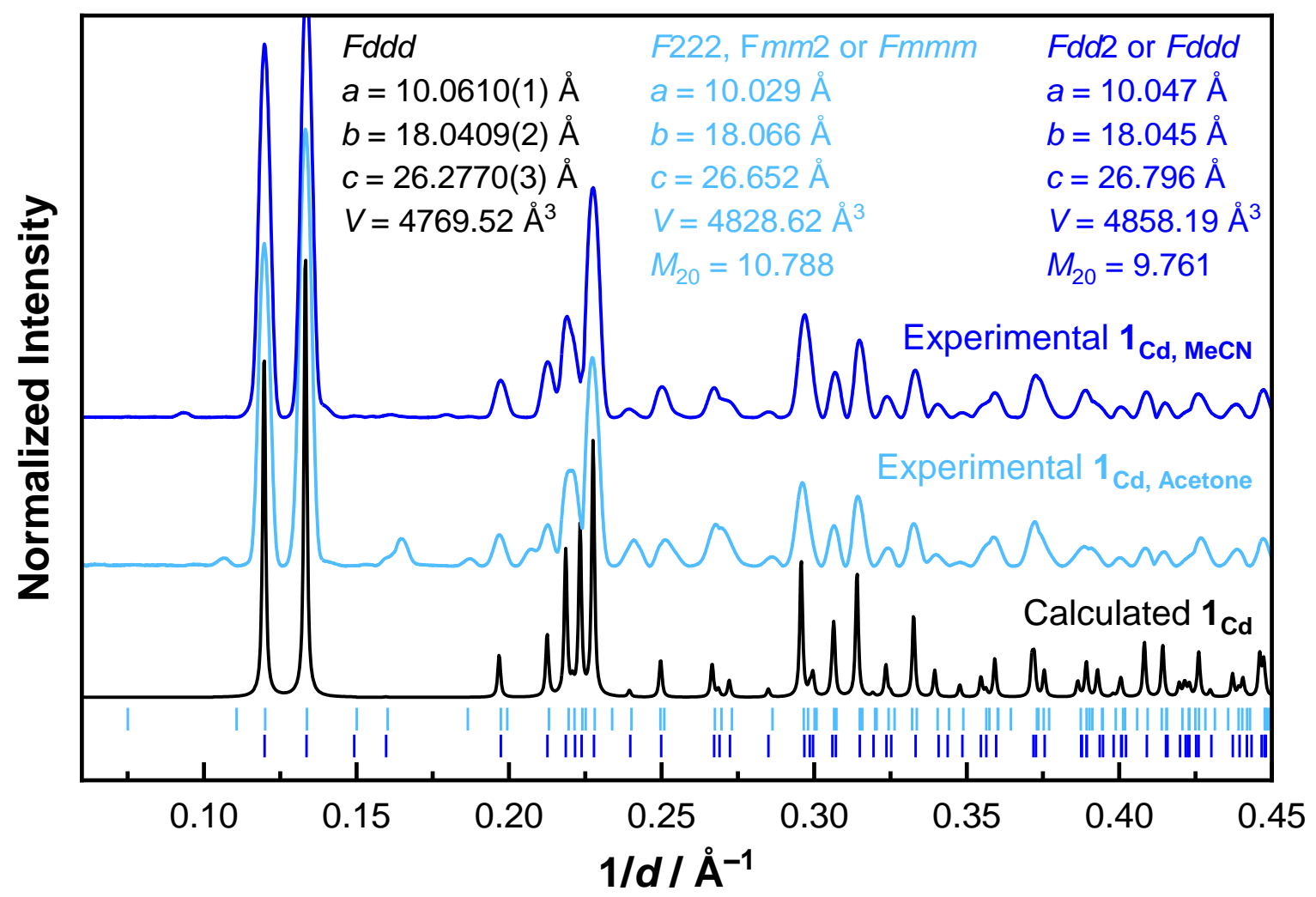

Figure S2. P-XRD ( $\lambda=1.54184 \AA$ ) pattern of 1 Cd synthesised using $\mathrm{MeCN}-\mathrm{H}_{2} \mathrm{O}$ (royal blue, $T=100 \mathrm{~K}$ ) or acetone $-\mathrm{H}_{2} \mathrm{O}$ (pale blue, $T=100 \mathrm{~K}$ ) solvent systems, and calculated pattern from SC-XRD of 1 Cd (black, $T=100 \mathrm{~K}$ ). Tick marks (royal and pale blue) indicate the positions of the allowed reflections for the unit cells indexed from the experimental P-XRD patterns. 


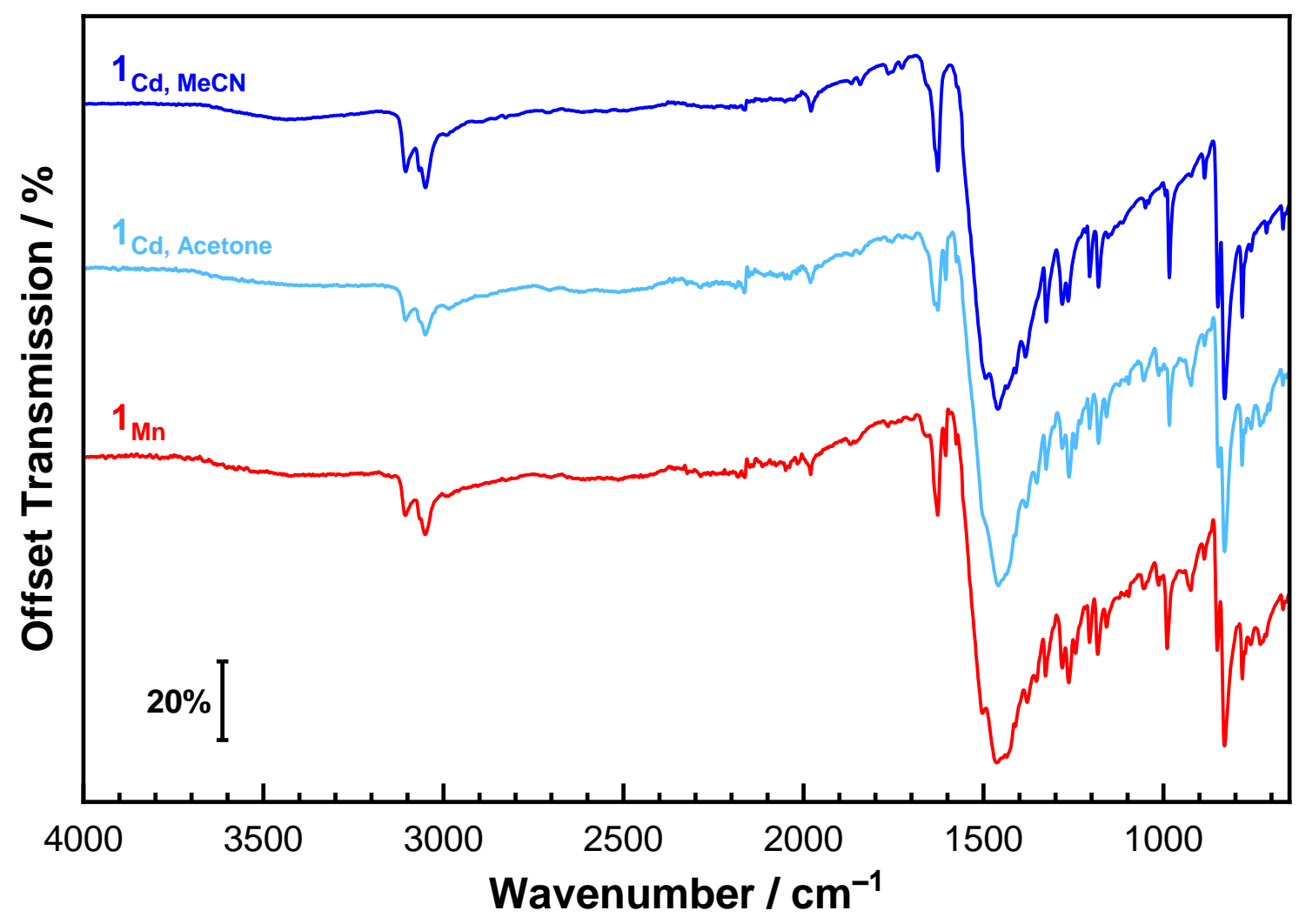

Figure S3. ATR FT-IR spectra of $\mathbf{1}_{\mathbf{M n}}$ (red), and $\mathbf{1}_{\mathbf{C d}}$ synthesised using either acetone- $\mathrm{H}_{2} \mathrm{O}$ (pale blue) or $\mathrm{MeCN}-\mathrm{H}_{2} \mathrm{O}$ (royal blue) solvent systems, collected at room temperature in air. 


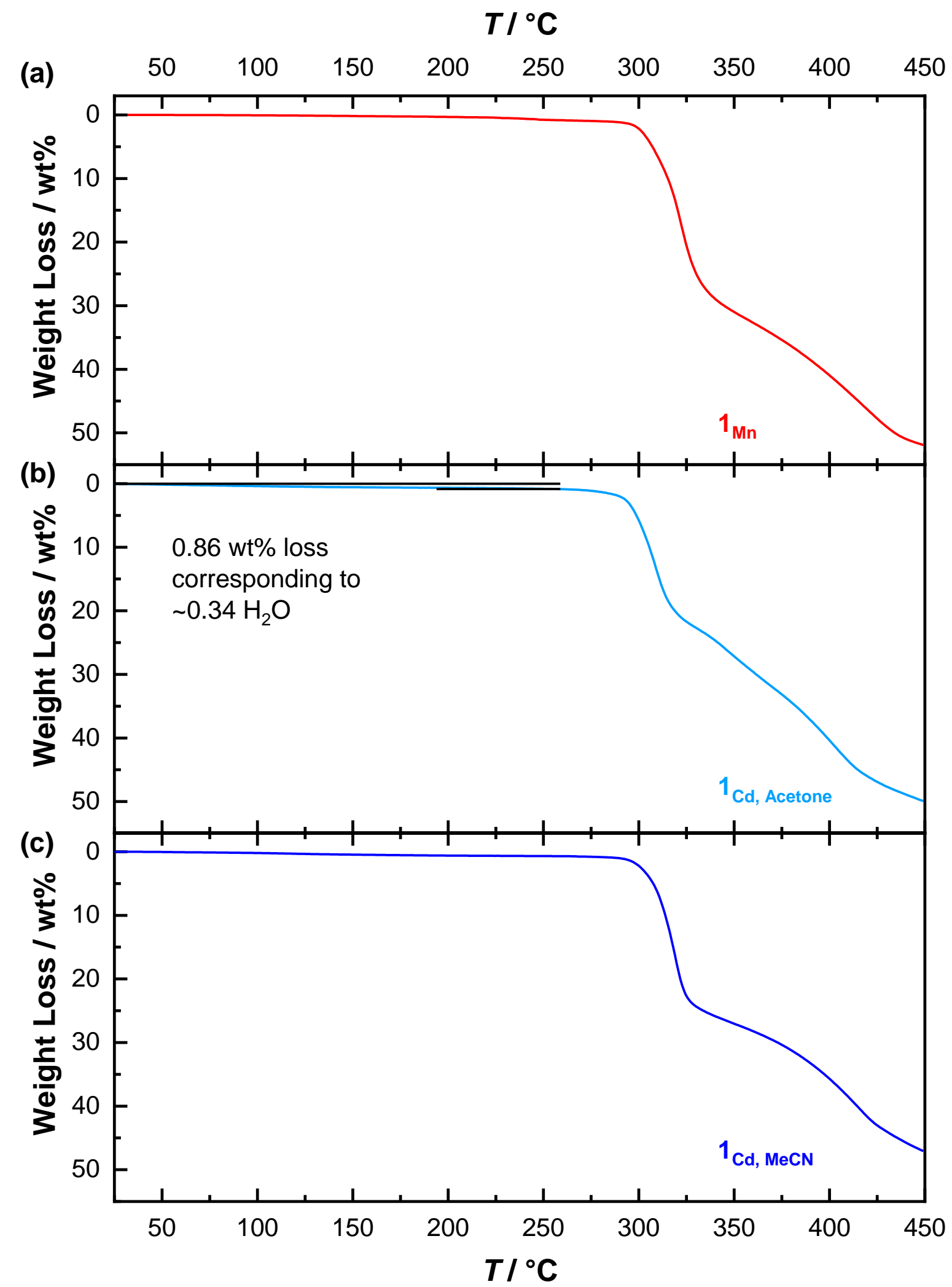

Figure S4. Thermogravimetric analyses of (a) $\mathbf{1}_{\mathbf{M n}}$ (red), and $\mathbf{1}_{\mathbf{C d}}$ synthesised using either (b) acetone- $\mathrm{H}_{2} \mathrm{O}$ (pale blue) or (c) $\mathrm{MeCN}-\mathrm{H}_{2} \mathrm{O}$ (royal blue) solvent systems. TGA was performed at a scan rate of $5^{\circ} \mathrm{C} \min ^{-1}$ in a flow of $\mathrm{N}_{2}$. 
Table S2. Analysis of the possible metal coordination geometries in $\mathbf{1}_{\mathbf{M n}}$ and $\mathbf{1}_{\mathrm{Cd}}$ quantified using Continuous Shape Measure (CShM) parameters. ${ }^{8,9}$

\begin{tabular}{ccc}
\hline $\begin{array}{c}\text { Coordination Geometry } \\
\text { (Symmetry) }\end{array}$ & Compound & \\
\hline OP-8 $\left(\boldsymbol{D}_{\mathbf{8 h}}\right)$ & 27.956 & $\mathbf{1}_{\mathbf{C d}}$ \\
\hline HPY-8 $\left(\boldsymbol{C}_{\mathbf{7 v}}\right)$ & 23.647 & 27.495 \\
\hline HBPY-8 $\left(\boldsymbol{D}_{\mathbf{6 h}}\right)$ & 16.730 & 23.272 \\
\hline CU-8 $\left(\boldsymbol{O}_{\mathbf{h}}\right)$ & 11.261 & 16.487 \\
\hline SAPR-8 $\left(\boldsymbol{D}_{\mathbf{4 d}}\right)$ & 2.961 & 10.945 \\
\hline TDD-8 $\left(\boldsymbol{D}_{\mathbf{2 d}}\right)$ & $\mathbf{0 . 9 6 4}$ & 2.927 \\
\hline JGBF-8 $\left(\boldsymbol{D}_{\mathbf{2 d}}\right)$ & 12.340 & $\mathbf{0 . 8 0 1}$ \\
\hline JETBPY-8 $\left(\boldsymbol{D}_{\mathbf{3 h}}\right)$ & 27.132 & 2.922 \\
\hline JBTPR-8 $\left(\boldsymbol{C}_{\mathbf{2 v}}\right)$ & 2.349 & 27.687 \\
\hline BTPR $\left(\boldsymbol{C}_{\mathbf{2 v}}\right)$ & 2.698 & 2.561 \\
\hline JSD-8 $\left(\boldsymbol{D}_{\mathbf{2 d}}\right)$ & 1.153 & 2.677 \\
TT-8 $\left(\boldsymbol{T}_{\mathbf{d}}\right)$ & 11.189 & 1.588 \\
\hline
\end{tabular}

OP-8: Octagon; HPY-8: Heptagonal pyramid; HBPY-8: Heptagonal bipyramid; CU-8: Cube; SAPR-8: Square antiprism; TDD-8: Triangular dodecahedron; JGBF-8: Johnson gyrobifastigium J26; JETBPY-8: Johnson elongated triangular bipyramid J14; JBTPR-8: Biaugmented trigonal prism J50; BTPR-8: Biaugmented trigonal prism; JSD-8: Sub diphenoid J84; TT-8: Triakis tetrahedron 


\section{Estimation of $\mathrm{MeV}^{m+}$ Valence State}

Variation of the bond lengths in viologen compounds, in particular the inter-ring $\mathrm{C}-\mathrm{C}$ bond, with changes in oxidation state is well known. ${ }^{10-12}$ The diagnostic bonds for $\mathrm{MeV}^{m+}$ species are given in Figure S5. As aromatic $\mathrm{MeV}^{2+}$ molecules undergo one electron reduction to the semiquinonoid $\mathrm{MeV}^{+\bullet}$ species, followed by a subsequent one electron reduction to the neutral quinonoid $\mathrm{MeV}^{0}$ form, bonds $b$ and $d$ decrease in length as they develop increasing double bond character, while bond $c$ increases in length as single bond character develops. Similarly to the methodology some of us have employed for determination of the oxidation state of TCNQ and $\mathrm{F}_{4}$ TCNQ in charge-transfer complexes and radical salts, ${ }^{13}, 14$ the oxidation state of $\mathrm{MeV}^{m+}$ species in coordination polymers can be determined by examination of particular $\mathrm{C}-\mathrm{C}$ bond lengths, using an empirical relationship introduced by Kistenmacher et al. for TCNQ, ${ }^{15}$

$$
q=A\left(\frac{c}{b+d}\right)+B
$$

where $q(-)$ is the estimated charge, $b, c$ and $d(\AA)$ are the bond lengths shown in Figure S5, and $A$ and $B$ are empirical fitting parameters calculated from analysis of SC-XRD structures of $\mathrm{MeV}^{0}, \mathrm{MeV}^{+\bullet}$ and $\mathrm{MeV}^{2+}$ species in literature (Table S3). Based upon these compounds, the $A$ and $B$ parameters were calculated to be -37.932 and 20.468 respectively.

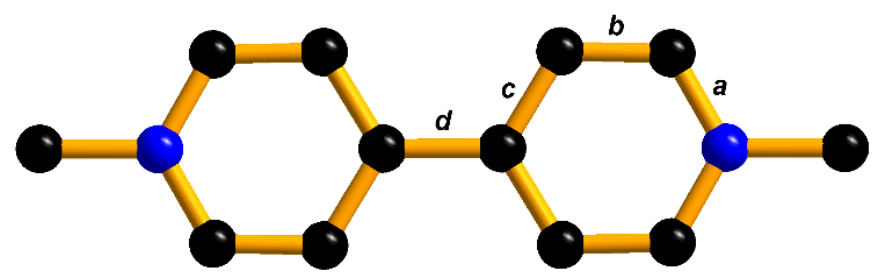

Figure S5. Diagnostic bond lengths in $\mathrm{MeV}^{m+}$ species for estimation of oxidation state. Blue $=\mathrm{N}$ and black $=\mathrm{C}$.

Table S3. Summary of the diagnostic mean bond lengths in $\mathrm{MeV}^{0}, \mathrm{MeV}^{+\bullet}$ and $\mathrm{MeV}^{2+}$ species reported in literature for calculation of Kistenmacher relationship parameters. NB. Where multiple values for the bond lengths are shown, they represent the mean values for crystallographically unique moieties in the asymmetric unit.

\begin{tabular}{ccccccccc}
\hline Compound & $\begin{array}{c}\text { Assumed } \\
\text { Charge }(\boldsymbol{m})\end{array}$ & $\boldsymbol{a} / \AA$ & $\boldsymbol{b} / \AA$ & $\boldsymbol{c} / \AA$ & $\boldsymbol{d} / \AA$ & $\boldsymbol{c} /(\boldsymbol{b}+\boldsymbol{d})$ & $\boldsymbol{q}$ & Ref. \\
\hline \multirow{2}{*}{$\mathrm{MeV}^{0}$} & 0 & 1.381 & 1.331 & 1.453 & 1.363 & 0.539 & 0.01 & 10 \\
\hline & 1.383 & 1.330 & 1.458 & 1.370 & 0.540 & -0.02 & \\
\hline$\left(\mathrm{MeV}^{+\bullet}\right) \mathrm{PF}_{6}$ & 1 & 1.357 & 1.342 & 1.437 & 1.399 & 0.524 & 0.58 & 10 \\
& 1 & 1.387 & 1.344 & 1.399 & 1.442 & 0.502 & 1.42 & \\
$\left(\mathrm{MeV}^{+\bullet}\right) \mathrm{BF}_{4}$ & 1.359 & 1.349 & 1.423 & 1.424 & 0.513 & 1.00 & 11 \\
& 2 & 1.355 & 1.355 & 1.426 & 1.427 & 0.513 & 1.02 & \\
\hline $\mathrm{MeV}^{2+}\left(\mathrm{PF}_{6}\right)_{2}$ & 1.328 & 1.354 & 1.383 & 1.485 & 0.487 & 1.99 & 16 \\
\hline
\end{tabular}


(a)
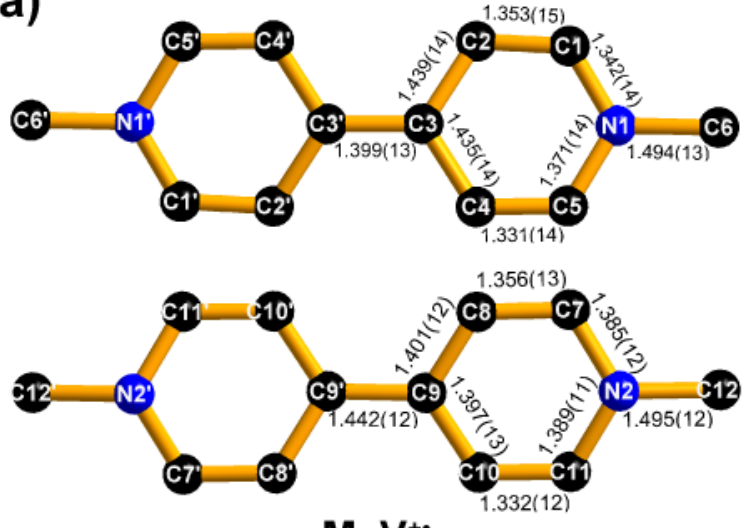

$\mathrm{MeV}^{+\cdot}$

(c)

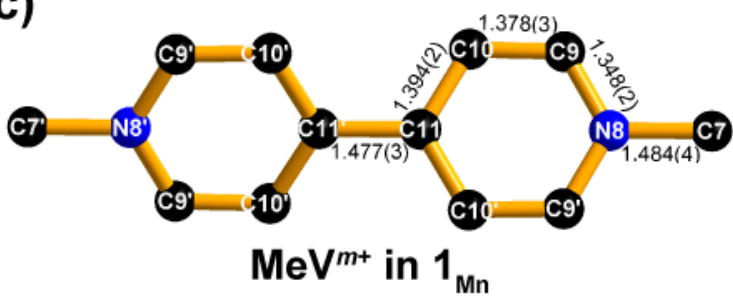

(b)

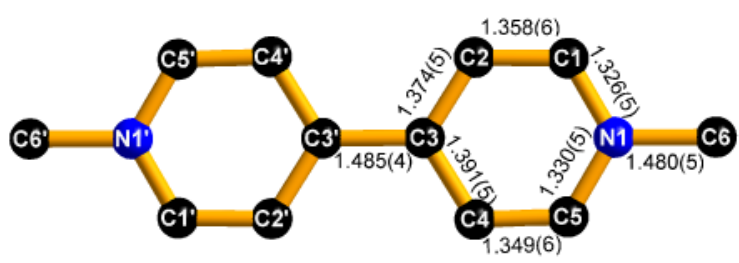

$\mathrm{MeV}^{2+}$

(d)

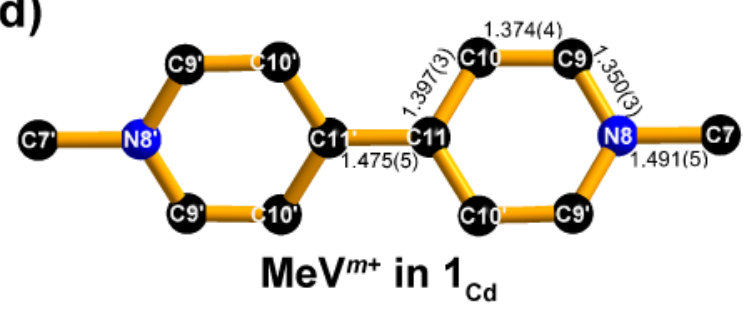

(e)

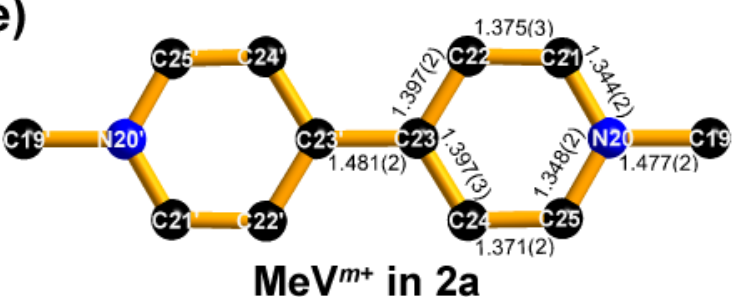

(f)

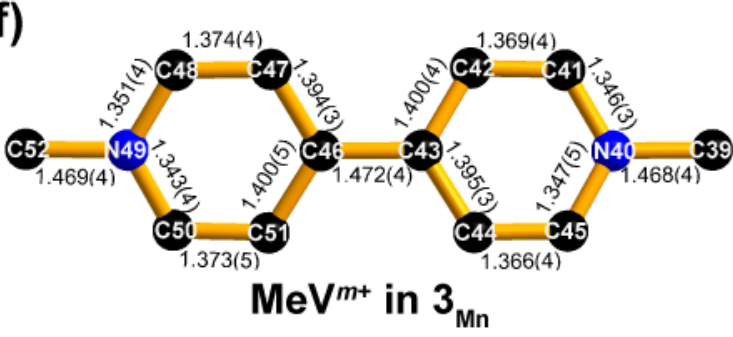

(g)

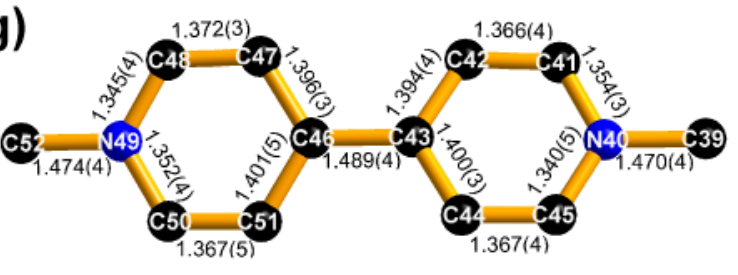

$\mathrm{MeV}^{\mathrm{m}+}$ in $3_{\mathrm{Cd}}$

Figure S6. Bond lengths in $\mathrm{MeV}^{m+}$ moieties in (a) $(\mathrm{MeV}) \mathrm{PF}_{6},{ }^{10}$ (b) $\mathrm{MeV}\left(\mathrm{PF}_{6}\right)_{2},{ }^{16}$, (c) $\mathbf{1}_{\mathrm{Mn}}$, (d) 1Cd, (e) 2a, (f) $\mathbf{3}_{\mathrm{Mn}}$ and (g) $\mathbf{3}_{\mathbf{C d}}$. For $(\mathrm{MeV}) \mathrm{PF}_{6}$, the two species shown are the crystallographically independent molecules in the asymmetric unit. Blue $=\mathrm{N}$ and black $=\mathrm{C}$. $\mathrm{H}$ atoms not shown for clarity. 
Table S4. Summary of the mean diagnostic bond lengths and estimated charge $(q)$ for $\mathrm{MeV}^{m+}$ moieties in coordination polymers in this work.

\begin{tabular}{cccccccc}
\hline Compound & $\boldsymbol{a} / \AA$ & $\boldsymbol{b} / \AA$ & $\boldsymbol{c} / \AA$ & $\boldsymbol{d} / \AA$ & $\boldsymbol{c} /(\boldsymbol{b}+\boldsymbol{d})$ & $\boldsymbol{q}$ \\
\hline $\mathbf{1}_{\mathbf{M n}}$ & 1.348 & 1.378 & 1.394 & 1.477 & 0.488 & 1.95 \\
$\mathbf{1}_{\mathbf{C d}}$ & 1.350 & 1.374 & 1.397 & 1.475 & 0.490 & 1.87 \\
\hline $\mathbf{2 a}$ & 1.346 & 1.373 & 1.397 & 1.481 & 0.489 & 1.90 \\
$\mathbf{3}_{\mathbf{M n}}$ & 1.347 & 1.371 & 1.397 & 1.472 & 0.492 & 1.82 \\
\hline $\mathbf{3}_{\mathbf{C d}}$ & 1.348 & 1.368 & 1.398 & 1.489 & 0.489 & 1.91 \\
\hline
\end{tabular}


(a)

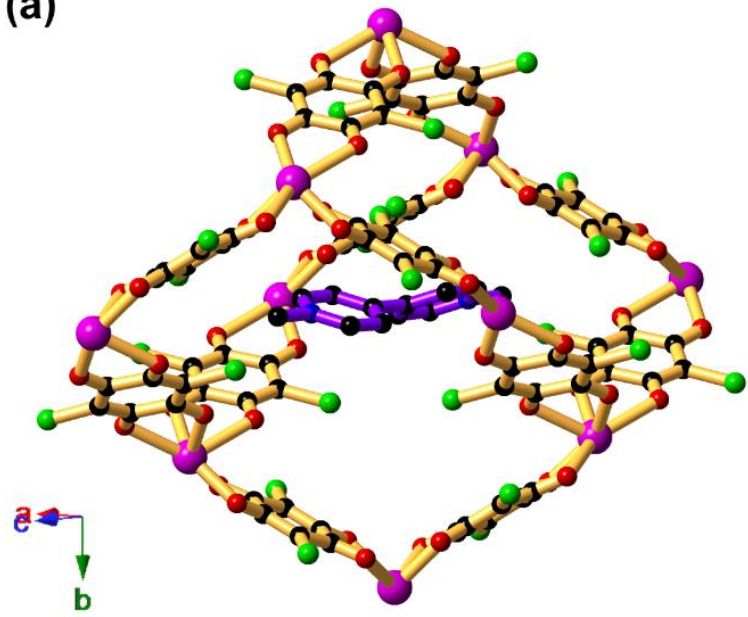

(c)

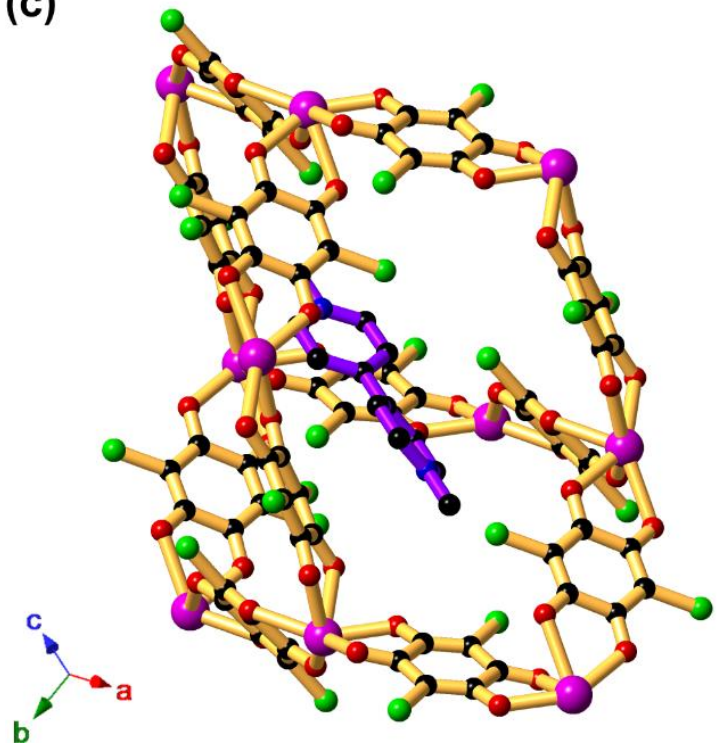

(b)

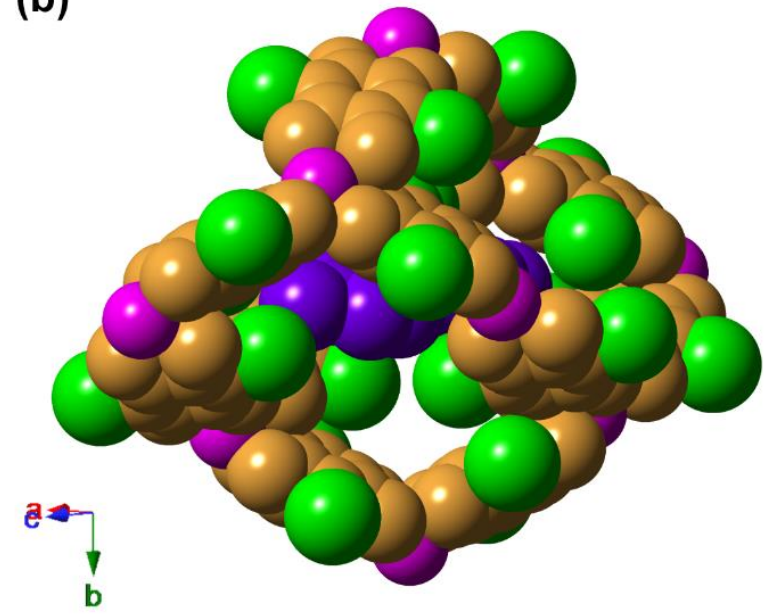

(d)

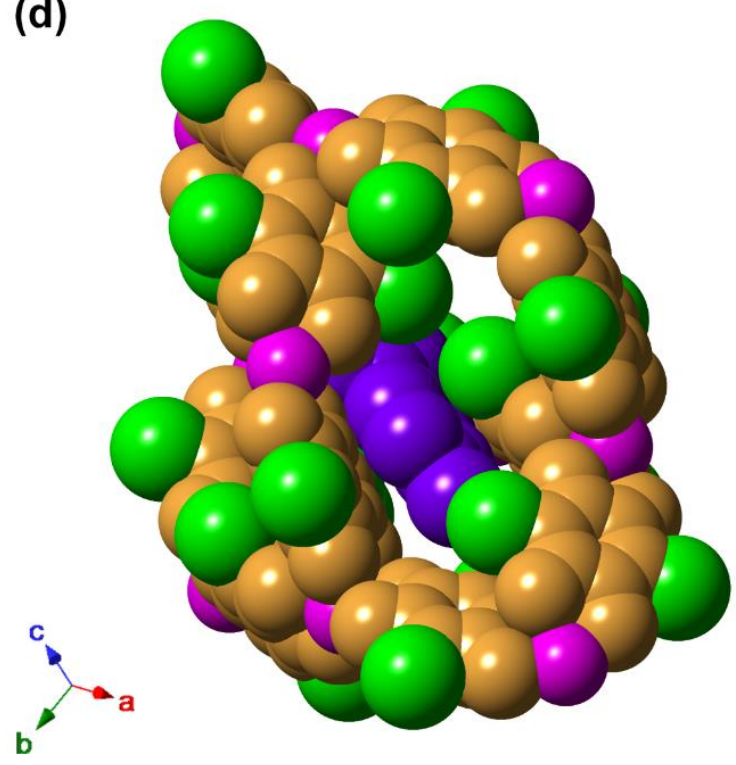

Figure S7. Ball-and-stick (a, c) and spacefilling (b, d) representations of the interactions between $\mathrm{MeV}^{2+}$ cations (purple) and the anionic $\left[\mathrm{Mn}(\mathrm{Clan})_{2}\right]^{2-}$ adamantane unit $(\tan )$ in $\mathbf{1}_{\mathbf{M n}}$. Magenta $=\mathrm{Mn}$, green $=\mathrm{Cl}$, red $=\mathrm{O}$, and black $=\mathrm{C} . \mathrm{H}$ atoms not shown for clarity. 
Table S5. Crystallographic data for the 2D honeycomb network 2a.

\begin{tabular}{|c|c|}
\hline Compound & $(\mathrm{MeV})\left[\mathrm{Mn}_{2}(\mathrm{Clan})_{3}\right] \cdot 6 \mathrm{MeCN}(\mathbf{2 a})$ \\
\hline $\begin{array}{l}\text { Empirical } \\
\text { formula }\end{array}$ & $\mathrm{C}_{21} \mathrm{H}_{16} \mathrm{~N}_{4} \mathrm{O}_{6} \mathrm{Cl}_{3} \mathrm{Mn}$ \\
\hline Formula weight & 581.67 \\
\hline Habit & Plate \\
\hline$T / \mathrm{K}$ & $100.0(5)$ \\
\hline Crystal system & Triclinic \\
\hline Space group & $P-1$ \\
\hline$a / \AA$ & $8.71340(10)$ \\
\hline$b / \AA$ & $11.69370(10)$ \\
\hline$c / \AA$ & $12.4715(2)$ \\
\hline$\alpha /{ }^{\circ}$ & $75.2910(10)$ \\
\hline$\beta /{ }^{\circ}$ & $78.4070(10)$ \\
\hline$\gamma /{ }^{\circ}$ & $83.1470(10)$ \\
\hline$V / \AA^{3}$ & $1200.89(3)$ \\
\hline$Z$ & 2 \\
\hline$\rho_{\text {calc }} / \mathrm{g} \mathrm{cm}^{-3}$ & 1.609 \\
\hline$\mu / \mathrm{mm}^{-1}$ & 7.950 \\
\hline$F_{000}$ & 588.0 \\
\hline Crystal size $/ \mathrm{mm}^{3}$ & $0.267 \times 0.17 \times 0.031$ \\
\hline Radiation & $\mathrm{Cu} \mathrm{K} \alpha(\lambda=1.54184 \AA)$ \\
\hline $2 \theta$ range $/^{\circ}$ & 7.448 to 148.96 \\
\hline Index ranges & $\begin{array}{l}-10 \leq h \leq 10 \\
-14 \leq k \leq 14 \\
-15 \leq l \leq 15\end{array}$ \\
\hline $\begin{array}{l}\text { Total/independent } \\
\text { reflections }\end{array}$ & $\begin{array}{l}40457 / 4893 \\
{\left[R_{\text {int }}=0.0405,\right.} \\
\left.R_{\text {sigma }}=0.0181\right]\end{array}$ \\
\hline $\begin{array}{l}\text { Data/restraints/ } \\
\text { parameters }\end{array}$ & $4893 / 153 / 320$ \\
\hline $\begin{array}{l}\text { Goodness-of-fit } \\
\text { on } F^{2}\end{array}$ & 1.029 \\
\hline $\begin{array}{l}\text { Final } R \text { indexes } \\
{[I \geq 2 \sigma(I)]}\end{array}$ & $\begin{array}{l}R_{1}=0.0253 \\
w R_{2}=0.0661\end{array}$ \\
\hline $\begin{array}{l}\text { Final } R \text { indexes } \\
\text { [all data] }\end{array}$ & $\begin{array}{l}R_{1}=0.0258 \\
w R_{2}=0.0664\end{array}$ \\
\hline $\begin{array}{l}\text { Largest diff. } \\
\text { peak/hole/ e } \AA^{-3}\end{array}$ & $0.31 /-0.30$ \\
\hline
\end{tabular}




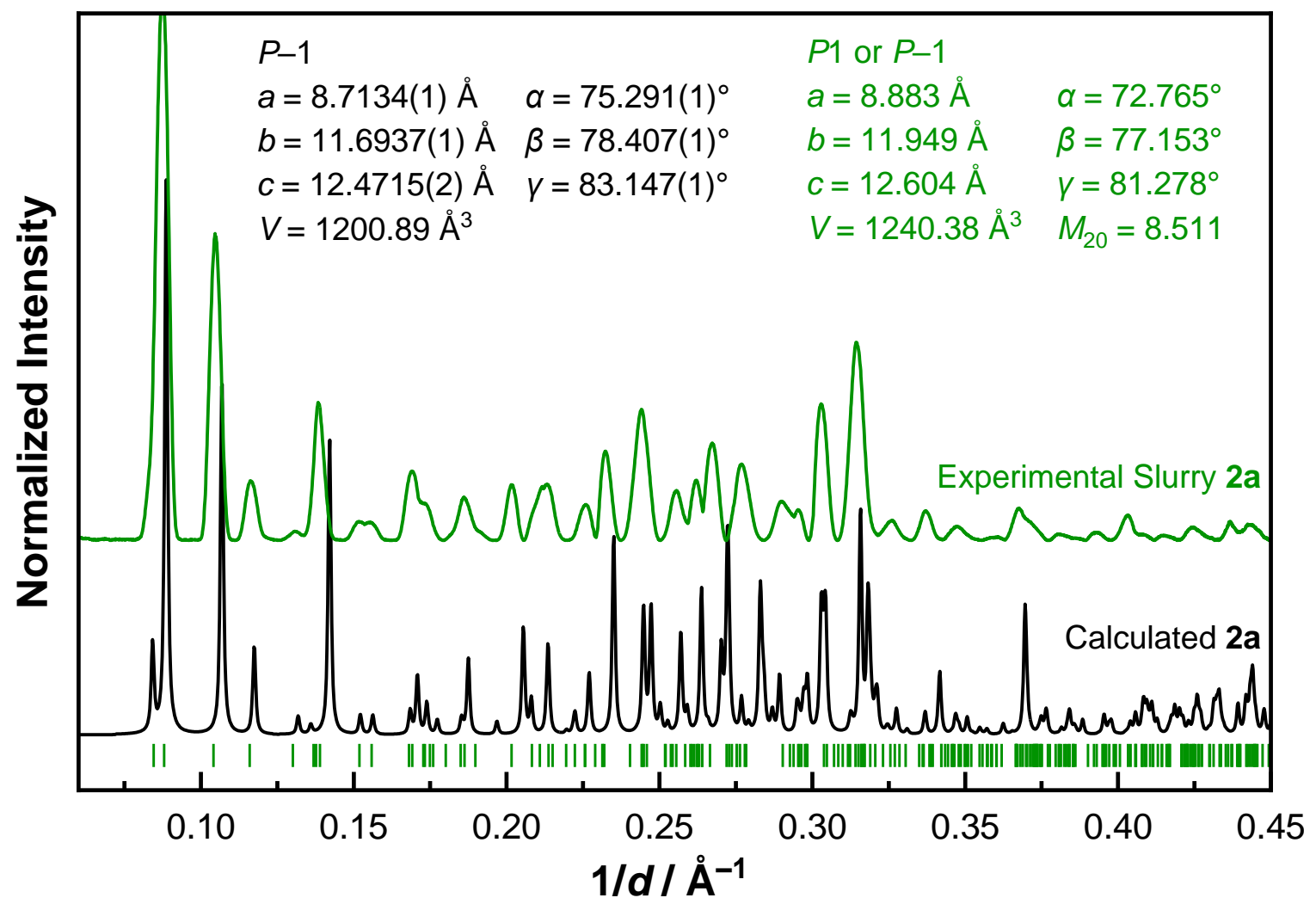

Figure S8. P-XRD $(\lambda=1.54184 \AA$ ) pattern of a MeCN slurry of bulk 2a (green, $T=250 \mathrm{~K}$ ) and calculated pattern from SC-XRD of 2a (black, $T=100 \mathrm{~K}$ ). Tick marks (green) indicate the positions of the allowed reflections for the unit cell indexed from the experimental P-XRD pattern. 
(a)
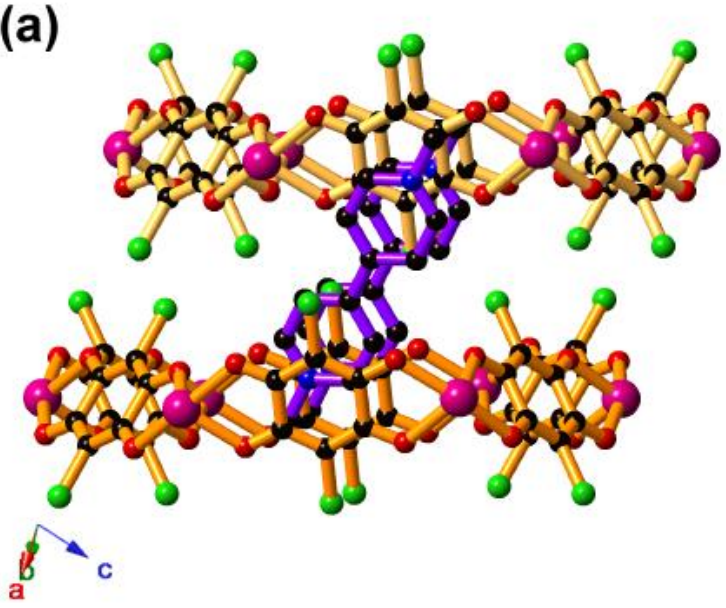

(c)

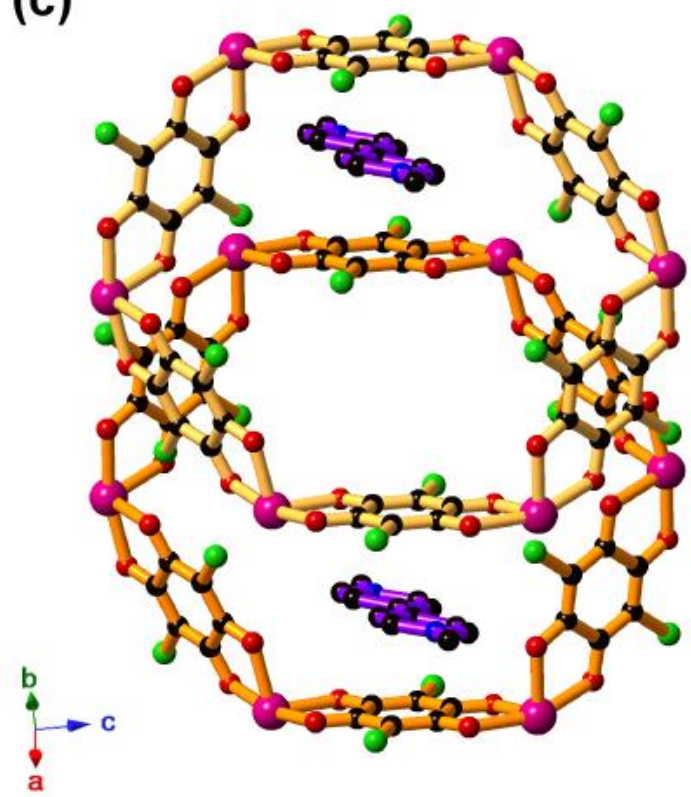

(b)

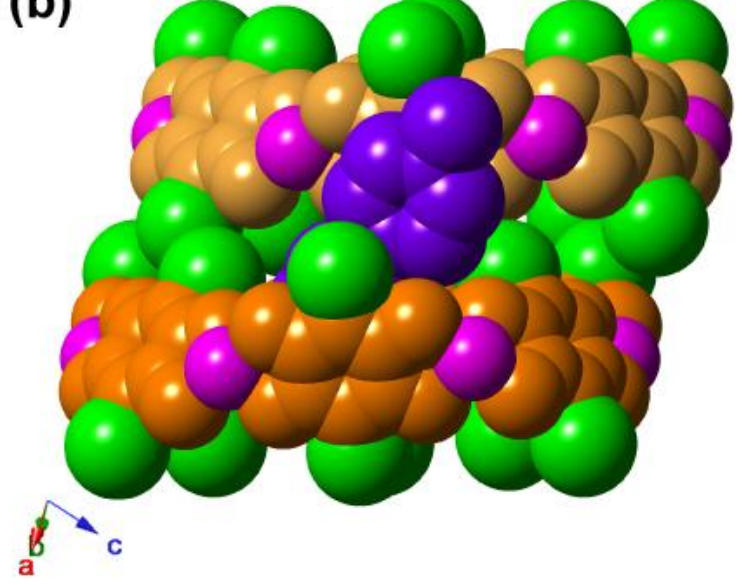

(d)

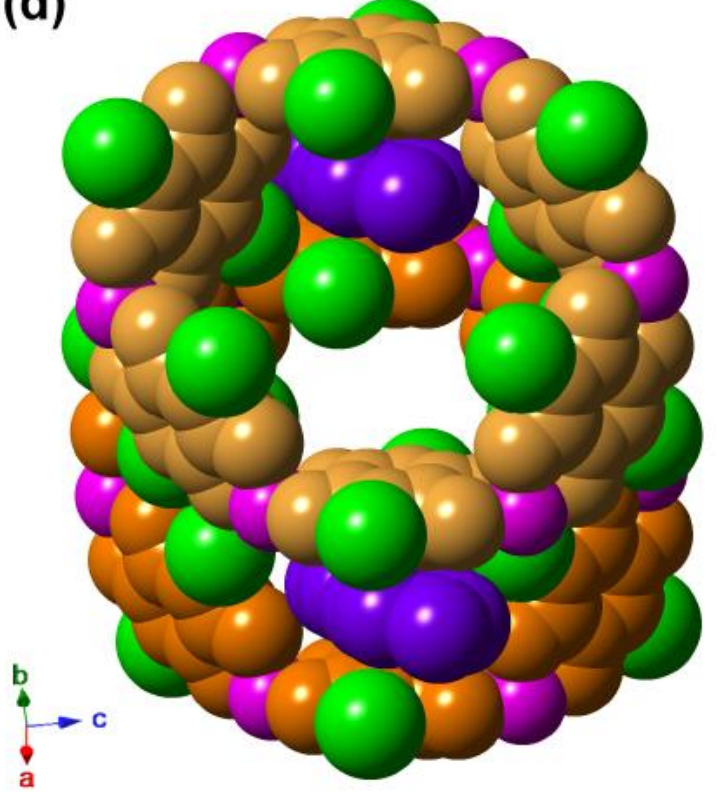

Figure S9. Ball-and-stick (a, c) and spacefilling (b, d) representations of the interactions between $\mathrm{MeV}^{2+}$ cations (purple) and anionic $\left[\mathrm{Mn}_{2}(\mathrm{Clan})_{3}\right]^{2-}$ sheets above (tan) and below (orange). Views along $(\mathrm{a}, \mathrm{b})$ the plane of the anionic $\left[\mathrm{Mn}_{2}(\mathrm{Clan})_{3}\right]^{2-}$ sheets, and $(\mathrm{c}, \mathrm{d})$ along the one-dimensional channels. Magenta $=\mathrm{Mn}$, green $=\mathrm{Cl}$, red $=\mathrm{O}$, blue $=\mathrm{N}$, black $=\mathrm{C} . \mathrm{H}$ atoms and ordered $\mathrm{MeCN}$ in channels not shown for clarity. 


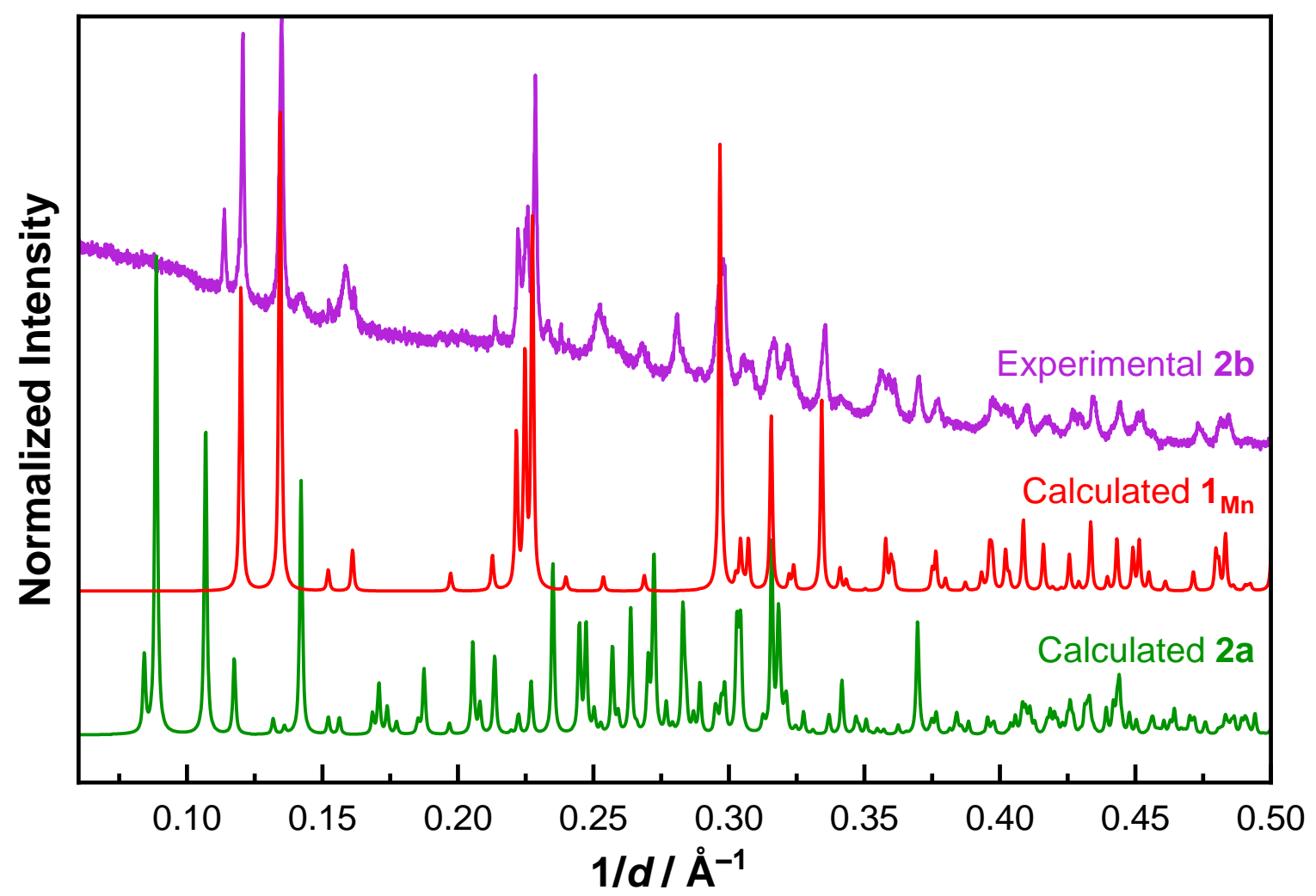

Figure S10. Synchrotron P-XRD $(\lambda=0.58835 \AA$ ) pattern of bulk $\mathbf{2 b}$ (i.e. isolated 2a, magenta, $T=100 \mathrm{~K}$ ) and calculated patterns from SC-XRD of $\mathbf{1}_{\mathrm{Mn}}(\mathrm{red}, T=100 \mathrm{~K}$ ) and $\mathbf{2 a}$ (green, $T=100 \mathrm{~K})$. 

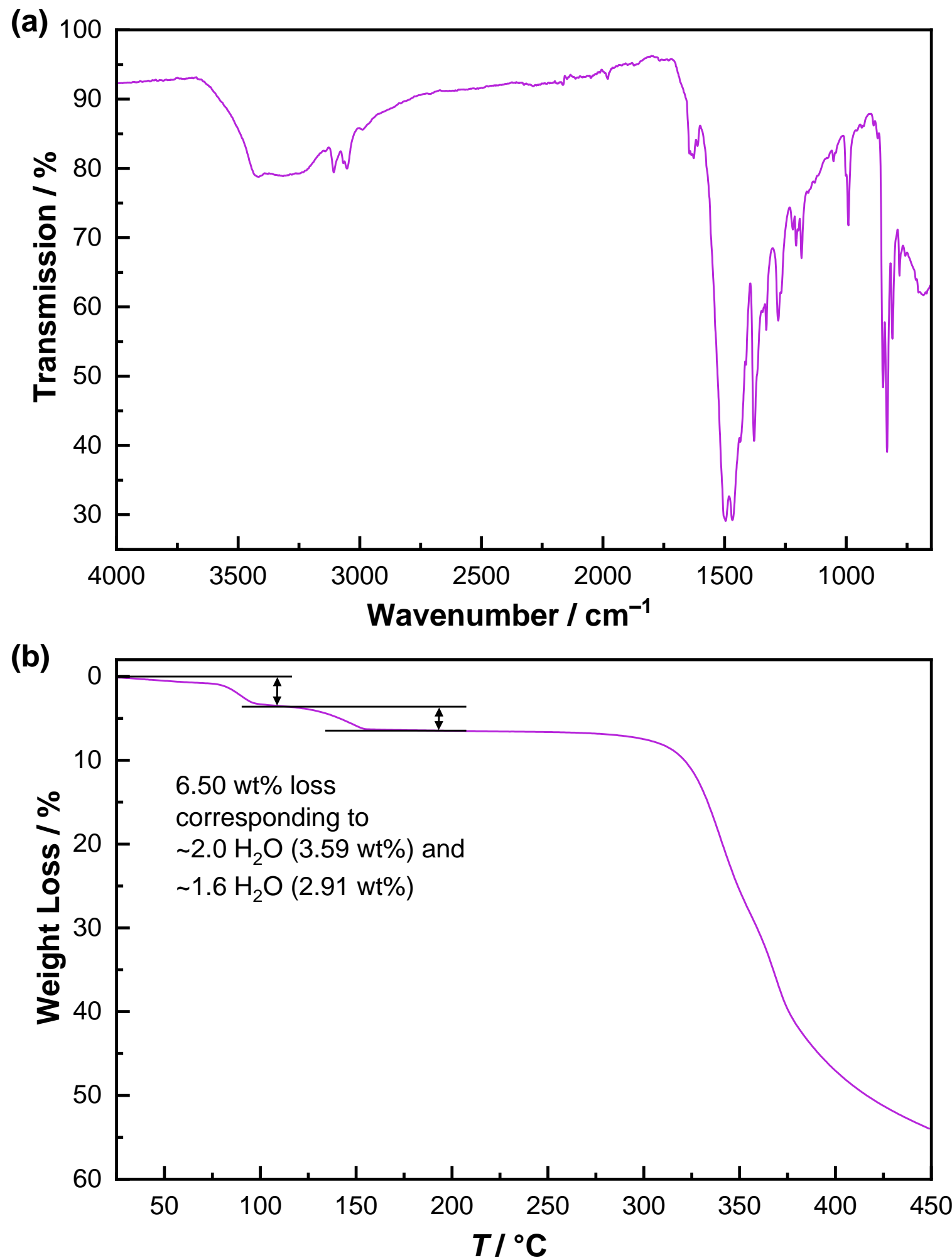

Figure S11. (a) ATR FT-IR spectrum of $\mathbf{2 b}$ collected at room temperature in air. (b) Thermogravimetric analysis of $\mathbf{2} \mathbf{b}$ showing two distinct mass loss processes. TGA was performed at a scan rate of $5{ }^{\circ} \mathrm{C} \mathrm{min}{ }^{-1}$ in a flow of $\mathrm{N}_{2}$. 
Table S6. Crystallographic data for the $1 \mathrm{D}$ coordination polymers $\mathbf{3}_{\mathbf{M n}}, \mathbf{3}_{\mathbf{C d}}$ and $\mathbf{4}_{\mathrm{Cd}}$.

\begin{tabular}{|c|c|c|c|}
\hline Compound & $\begin{array}{l}(\mathrm{MeV})\left[\mathrm{Mn}_{2}(\mathrm{Fan})_{3}\right. \\
\left.\left(\mathrm{H}_{2} \mathrm{O}\right)_{2}\right] \cdot 2 \mathrm{MeCN} \cdot \\
0.5 \mathrm{H}_{2} \mathrm{O}\left(\mathbf{3}_{\mathbf{M n}}\right)\end{array}$ & $\begin{array}{l}(\mathrm{MeV})\left[\mathrm{Cd}_{2}(\mathrm{Fan})_{3}\right. \\
\left.\left(\mathrm{H}_{2} \mathrm{O}\right)_{2}\right] \cdot 2 \mathrm{MeCN} \cdot \\
0.6 \mathrm{H}_{2} \mathrm{O}\left(\mathbf{3}_{\mathrm{Cd}}\right)\end{array}$ & {$\left[\mathrm{Cd}(\mathrm{Fan})\left(\mathrm{H}_{2} \mathrm{O}\right)_{2}\right]\left(\mathbf{4}_{\mathrm{Cd}}\right)$} \\
\hline Empirical formula & $\mathrm{C}_{34} \mathrm{H}_{25} \mathrm{~N}_{4} \mathrm{O}_{14.5} \mathrm{~F}_{6} \mathrm{Mn}_{2}^{\mathrm{a}}$ & $\mathrm{C}_{34} \mathrm{H}_{25.2} \mathrm{~N}_{4} \mathrm{O}_{14.6} \mathrm{~F}_{6} \mathrm{Cd}_{2}{ }^{\mathrm{b}}$ & $\mathrm{C}_{6} \mathrm{H}_{4} \mathrm{CdF}_{2} \mathrm{O}_{6}$ \\
\hline Formula weight & $945.46^{\mathrm{a}}$ & $1062.18^{\mathrm{b}}$ & 322.49 \\
\hline Habit & Plate & Plate & Plate \\
\hline$T / \mathrm{K}$ & $100.00(1)$ & $100.00(10)$ & 100.15 \\
\hline Crystal system & Triclinic & Triclinic & Monoclinic \\
\hline Space group & $P-1$ & $P-1$ & $C 2 / m$ \\
\hline$a / \AA$ & $11.9381(2)$ & $12.01850(10)$ & $6.6686(13)$ \\
\hline$b / \AA$ & $12.4271(2)$ & $12.37350(10)$ & $8.0832(16)$ \\
\hline$c / \AA$ & $13.8921(2)$ & $13.86430(10)$ & $8.1130(16)$ \\
\hline$\alpha /{ }^{\circ}$ & $97.9620(10)$ & $96.0150(10)$ & 90 \\
\hline$\beta 1^{\circ}$ & $114.4250(10)$ & $114.1410(10)$ & $112.03(3)$ \\
\hline$\gamma /{ }^{\circ}$ & $95.4990(10)$ & $95.2320(10)$ & 90 \\
\hline$V / \AA^{3}$ & $1831.45(5)$ & $1850.57(3)$ & $405.40(16)$ \\
\hline$Z$ & 2 & 2 & 2 \\
\hline$\rho_{\text {calc }} / \mathrm{g} \mathrm{cm}^{-3}$ & 1.714 & 1.906 & 2.642 \\
\hline$\mu / \mathrm{mm}^{-1}$ & 6.592 & 10.180 & 2.738 \\
\hline$F_{000}$ & $954.0^{\mathrm{a}}$ & $1048.0^{\mathrm{b}}$ & 308.0 \\
\hline Crystal size $/ \mathrm{mm}^{3}$ & $0.194 \times 0.085 \times 0.022$ & $0.252 \times 0.14 \times 0.035$ & $0.05 \times 0.05 \times 0.01$ \\
\hline Radiation & $\mathrm{Cu} \mathrm{K} \alpha(\lambda=1.54184 \AA)$ & $\mathrm{Cu} \mathrm{K} \alpha(\lambda=1.54184 \AA)$ & $\begin{array}{l}\text { Synchrotron } \\
(\lambda=0.71073 \AA)\end{array}$ \\
\hline $2 \theta$ range $/^{\circ}$ & 7.128 to 155.914 & 7.074 to 156.264 & 5.416 to 63.014 \\
\hline Index ranges & $\begin{array}{l}-15 \leq h \leq 14 \\
-15 \leq k \leq 15 \\
-15 \leq l \leq 17\end{array}$ & $\begin{array}{l}-14 \leq h \leq 15 \\
-15 \leq k \leq 15 \\
-17 \leq l \leq 17\end{array}$ & $\begin{array}{l}-9 \leq h \leq 9 \\
-11 \leq k \leq 11 \\
-10 \leq l \leq 10\end{array}$ \\
\hline $\begin{array}{l}\text { Total/independent } \\
\text { reflections }\end{array}$ & $\begin{array}{l}28688 / 7660 \\
{\left[R_{\text {int }}=0.0390,\right.} \\
\left.R_{\text {sigma }}=0.0368\right]\end{array}$ & $\begin{array}{l}28800 / 7747 \\
{\left[R_{\text {int }}=0.0340,\right.} \\
\left.R_{\text {sigma }}=0.0296\right]\end{array}$ & $\begin{array}{l}3614 / 629 \\
{\left[R_{\text {int }}=0.0622,\right.} \\
\left.R_{\text {sigma }}=0.0312\right]\end{array}$ \\
\hline $\begin{array}{l}\text { Data/restraints/ } \\
\text { parameters }\end{array}$ & $7660 / 132 / 533$ & $7747 / 252 / 544$ & $629 / 2 / 43$ \\
\hline $\begin{array}{l}\text { Goodness-of-fit on } \\
F^{2}\end{array}$ & 1.038 & 1.080 & 1.149 \\
\hline $\begin{array}{l}\text { Final } R \text { indexes } \\
{[I \geq 2 \sigma(I)]}\end{array}$ & $\begin{array}{l}R_{1}=0.0359 \\
w R_{2}=0.0977\end{array}$ & $\begin{array}{l}R_{1}=0.0251, \\
w R_{2}=0.0674\end{array}$ & $\begin{array}{l}R_{1}=0.0306 \\
w R_{2}=0.0809\end{array}$ \\
\hline $\begin{array}{l}\text { Final } R \text { indexes } \\
\text { [all data] }\end{array}$ & $\begin{array}{l}R_{1}=0.0437 \\
w R_{2}=0.1039\end{array}$ & $\begin{array}{l}R_{1}=0.0270, \\
w R_{2}=0.0686\end{array}$ & $\begin{array}{l}R_{1}=0.306 \\
w R_{2}=0.089\end{array}$ \\
\hline $\begin{array}{l}\text { Largest diff. } \\
\text { peak/hole/ e } \AA^{-3}\end{array}$ & $0.35 /-0.44$ & $0.44 /-0.84$ & $2.02 /-1.41$ \\
\hline
\end{tabular}

Includes contribution of ${ }^{\mathrm{a}}$ : one $\mathrm{MeCN}$ and $0.5 \mathrm{H}_{2} \mathrm{O}\left(\mathbf{3}_{\mathbf{M n}}\right)$; ${ }^{\mathrm{b}}$ : and one $\mathrm{MeCN}$ and $0.6 \mathrm{H}_{2} \mathrm{O}\left(\mathbf{3}_{\mathbf{C d}}\right)$ disordered molecules per formula unit. The scattering contribution was accounted using the SQUEEZE $^{4}$ routine in PLATON. ${ }^{5}$ 


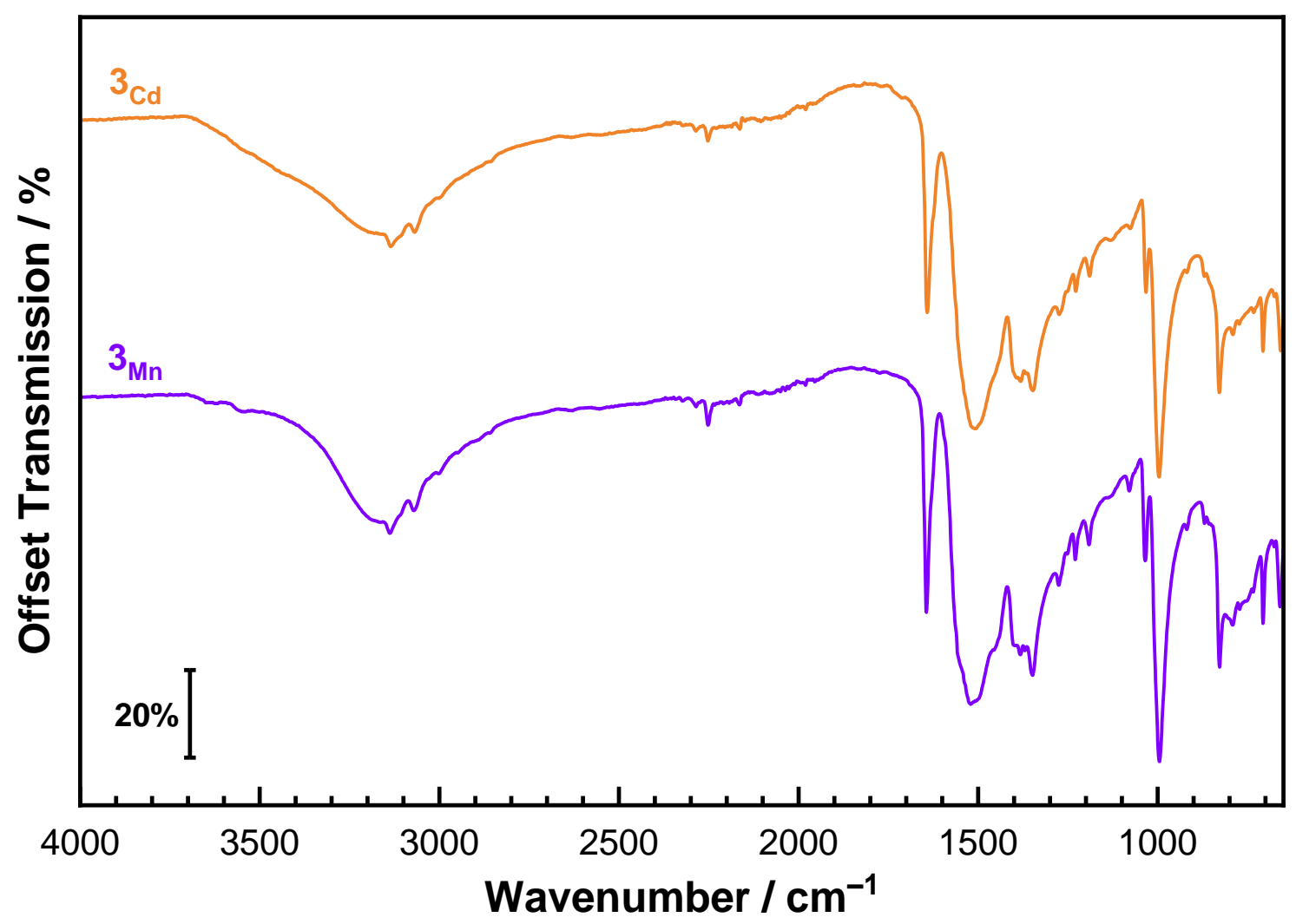

Figure S12. ATR FT-IR spectra of $\mathbf{3}_{\mathbf{M n}}$ (purple) and $\mathbf{3}_{\mathbf{C d}}$ (orange) collected at room temperature in air. 


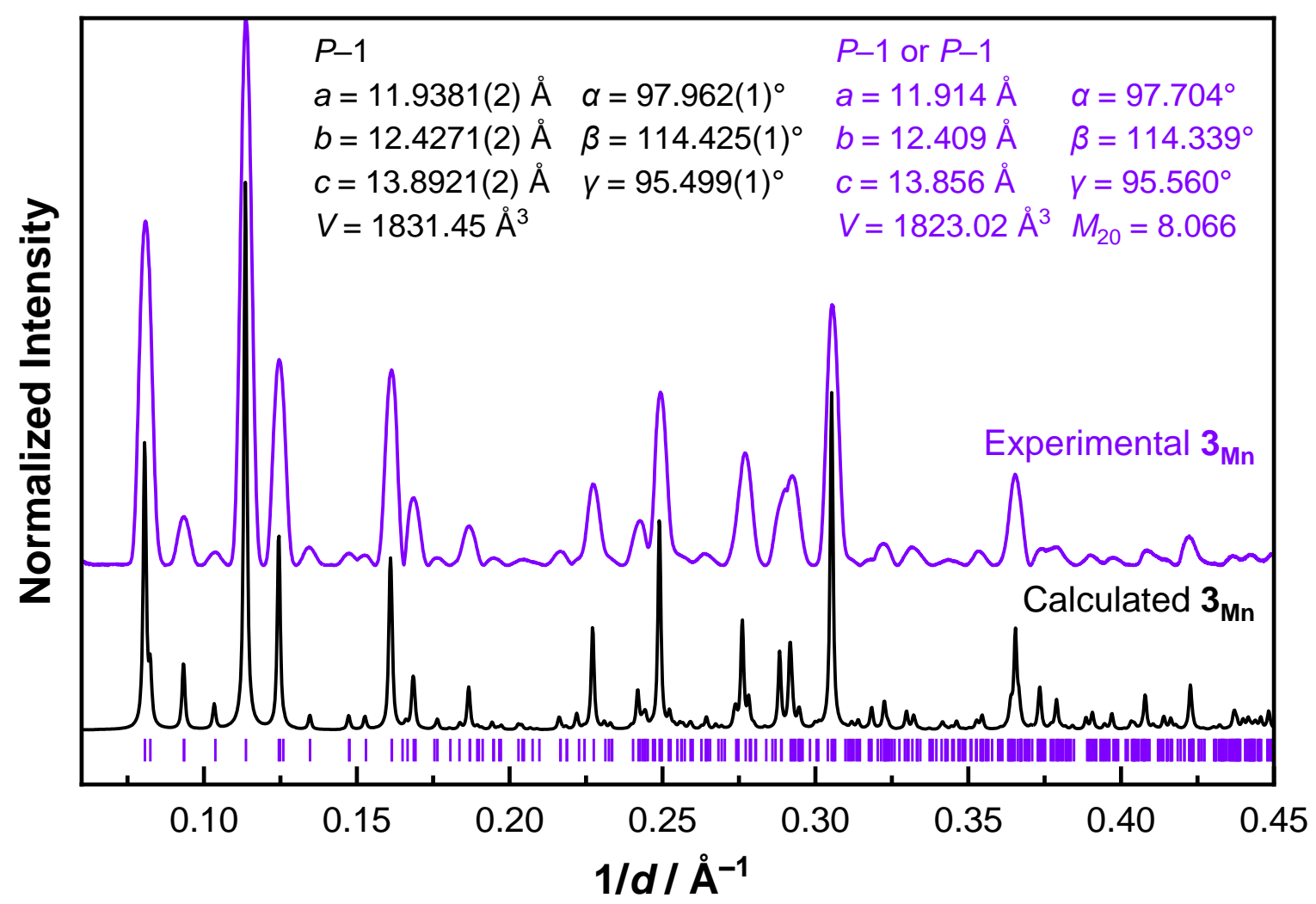

Figure S13. P-XRD $\left(\lambda=1.54184 \AA\right.$ ) pattern of $\mathbf{3}_{\mathrm{Mn}}$ (purple, $\left.T=100 \mathrm{~K}\right)$ and calculated pattern from SC-XRD of $\mathbf{3}_{\mathrm{Mn}}$ (black, $T=100 \mathrm{~K}$ ). Tick marks (purple) indicate the positions of the allowed reflections for the unit cell indexed from the experimental P-XRD pattern. 


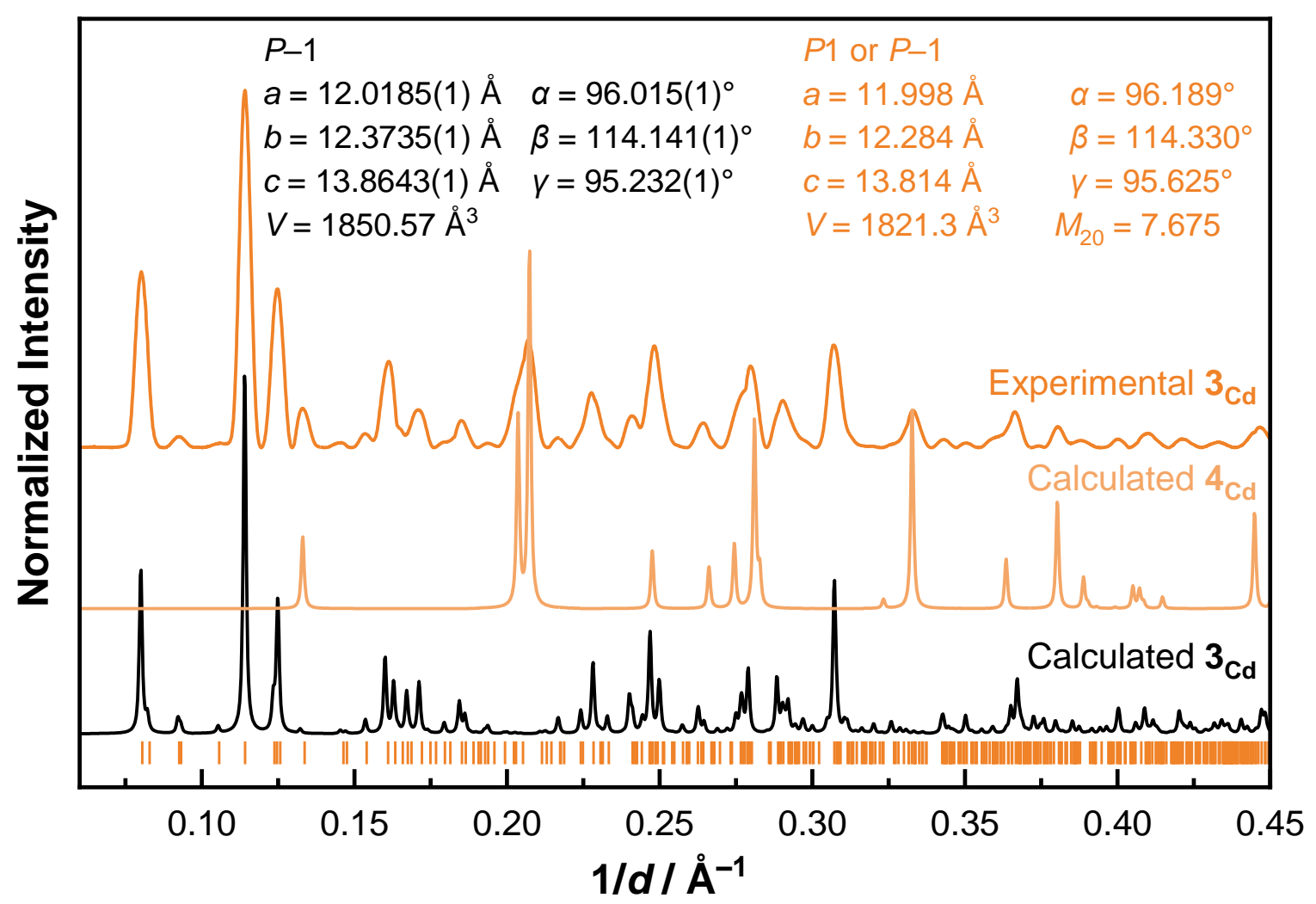

Figure S14. P-XRD $(\lambda=1.54184 \AA)$ pattern of bulk $3 \mathrm{Cd}$ (dark orange, $T=100 \mathrm{~K}$ ) and calculated patterns from SC-XRD of $\mathbf{3}_{\mathrm{Cd}}$ (black, $T=100 \mathrm{~K}$ ) and $\mathbf{4}_{\mathrm{Cd}}$ (light orange, $T=100 \mathrm{~K}$ ). Tick marks (dark orange) indicate the positions of the allowed reflections for the state unit cell indexed from the experimental P-XRD pattern. NB: Peaks in the experimental P-XRD attributed to the $\mathbf{4}_{\mathrm{Cd}}$ phase have been excluded from the pattern indexing. 
(a)

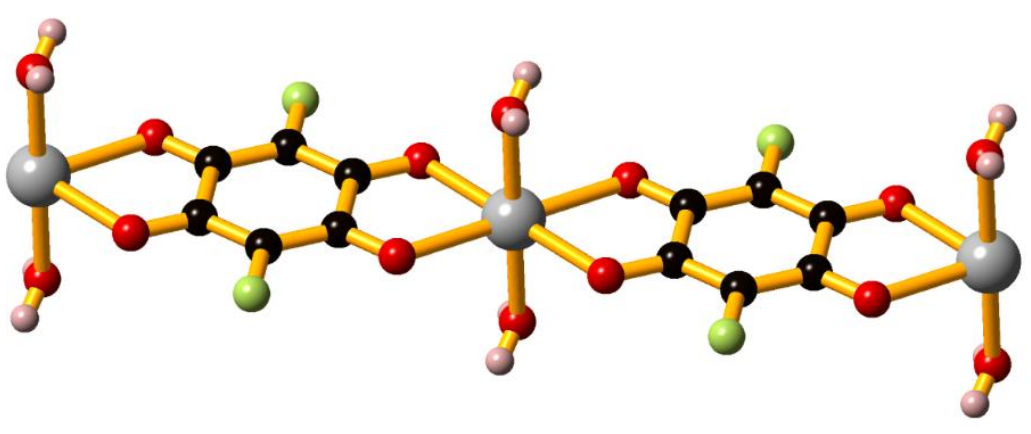

(b)

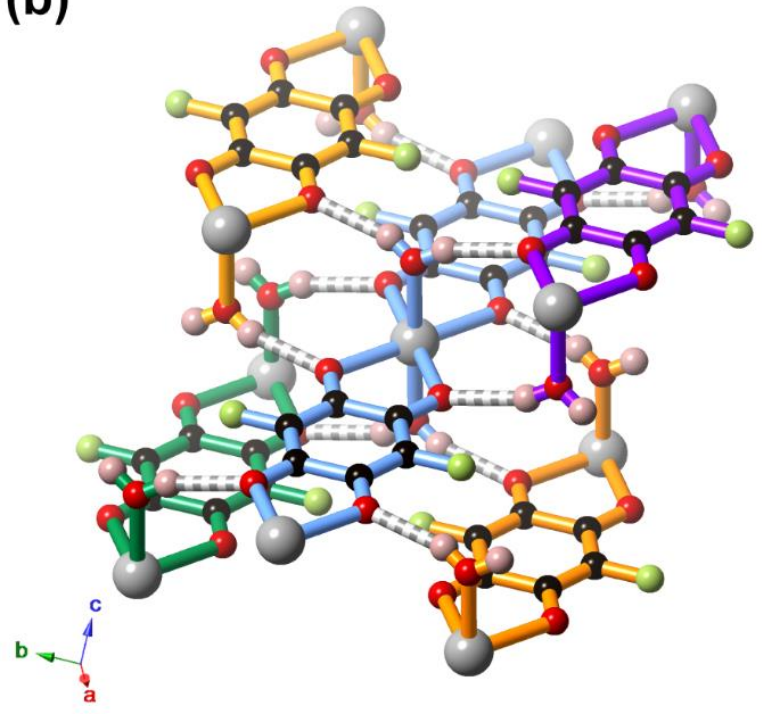

(c)

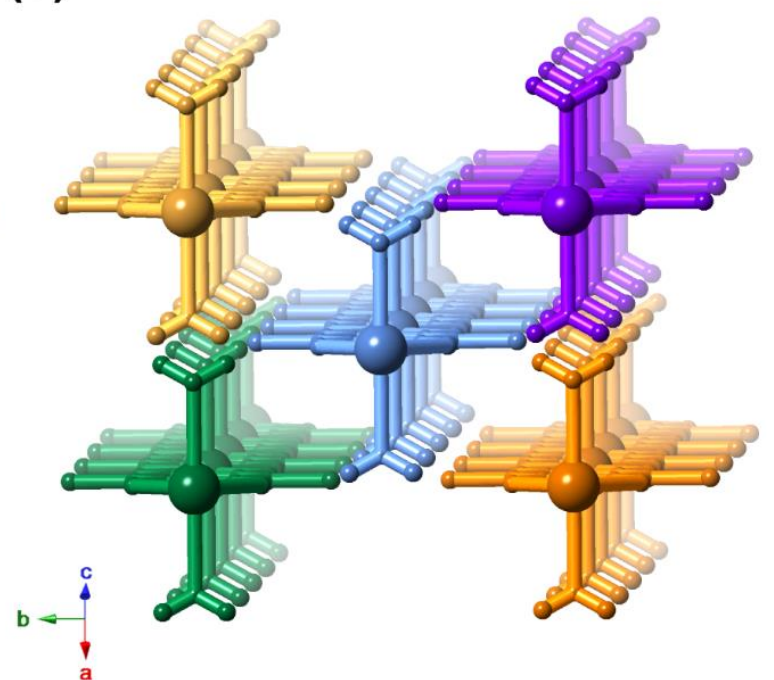

Figure S15. The structure of $\left[\mathrm{Cd}(\mathrm{Fan})\left(\mathrm{H}_{2} \mathrm{O}\right)_{2}\right]\left(\mathbf{4}_{\mathrm{Cd}}\right)$ 1D strip coordination polymer. (a) Coordination environment around $\mathrm{Cd}^{\mathrm{II}}$ centres in $\mathbf{4}_{\mathbf{C d}}$. (b) H-bonding interactions betweens each coordinated $\mathrm{H}_{2} \mathrm{O}$ molecule and adjacent $\left[\mathrm{Cd}(\mathrm{Fan})\left(\mathrm{H}_{2} \mathrm{O}\right)_{2}\right]$ strips in $\mathbf{4}_{\mathbf{C d}}$. (c) Packing arrangement of $\left[\mathrm{Cd}(\mathrm{Fan})\left(\mathrm{H}_{2} \mathrm{O}\right)_{2}\right]$ with adjacent $1 \mathrm{D}$ strips in $\mathbf{4}_{\mathbf{C d}}$. 
Table S7. Atomic separations and angles involving selected close contacts between $\mathrm{C}-\mathrm{H}$ units of $\mathrm{MeV}^{2+}$ cations with $\mathrm{Clan}^{2-}$ and Fan ${ }^{2-}$ ligands within $\mathbf{1}_{\mathbf{M n}}, \mathbf{1}_{\mathbf{C d}}, \mathbf{2 a}, \mathbf{3}_{\mathbf{M n}}$ and $\mathbf{3} \mathbf{C d}$.

\begin{tabular}{|c|c|c|c|c|}
\hline Compound & Atoms & $\mathbf{H} \cdots \mathbf{X} / \AA$ & C-H $\cdots \mathbf{X} / \AA$ & $\mathrm{C}-\mathrm{H} \cdot \cdots \mathrm{X} /{ }^{\circ}$ \\
\hline \multirow[t]{2}{*}{$\mathbf{1}_{\mathrm{Mn}}$} & $\mathrm{C} 10-\mathrm{H} 10 \cdots \mathrm{O} 1^{\mathrm{I}}$ & 2.51 & 3.44 & 166.6 \\
\hline & 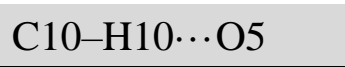 & 2.56 & 3.19 & 124.7 \\
\hline \multirow[t]{2}{*}{$1 \mathrm{Cd}$} & $\mathrm{C} 10-\mathrm{H} 10 \cdots \mathrm{O} 1^{\mathrm{II}}$ & 2.53 & 3.46 & 164.9 \\
\hline & $\mathrm{C} 10-\mathrm{H} 10 \cdots \mathrm{O} 5^{\mathrm{III}}$ & 2.56 & 3.20 & 124.6 \\
\hline \multirow[t]{2}{*}{$2 \mathbf{a}$} & $\mathrm{C} 22-\mathrm{H} 22 \cdots \mathrm{O} 13^{\mathrm{IV}}$ & 2.38 & 3.32 & 170.4 \\
\hline & $\mathrm{C} 24-\mathrm{H} 24 \cdots \mathrm{O} 13^{\mathrm{V}}$ & 2.41 & 3.34 & 166.1 \\
\hline \multirow[t]{4}{*}{$3 \mathrm{Mn}$} & $\mathrm{C} 50-\mathrm{H} 50 \cdots \mathrm{O} 1^{\mathrm{VI}}$ & 2.27 & 3.13 & 150.0 \\
\hline & $\mathrm{C} 45-\mathrm{H} 45 \cdots \mathrm{O} 36^{\mathrm{VI}}$ & 2.44 & 2.99 & 116.5 \\
\hline & $\mathrm{C} 42-\mathrm{H} 42 \cdots \mathrm{O} 15^{\mathrm{VII}}$ & 2.49 & 3.41 & 164.1 \\
\hline & $\mathrm{C} 48-\mathrm{H} 48 \cdots \mathrm{F} 18^{\mathrm{VII}}$ & 2.29 & 2.91 & 157.4 \\
\hline \multirow[t]{4}{*}{$3 \mathrm{Cd}$} & $\mathrm{C} 50-\mathrm{H} 50 \cdots \mathrm{O} 1^{\mathrm{VI}}$ & 2.27 & 3.11 & 148.0 \\
\hline & $\mathrm{C} 45-\mathrm{H} 45 \cdots \mathrm{O} 36^{\mathrm{VI}}$ & 2.43 & 3.04 & 121.3 \\
\hline & $\mathrm{C} 42-\mathrm{H} 42 \cdots \mathrm{O} 15^{\mathrm{VII}}$ & 2.44 & 3.37 & 166.2 \\
\hline & $\mathrm{C} 48-\mathrm{H} 48 \cdots \mathrm{F} 18^{\mathrm{VII}}$ & 2.29 & 2.92 & 123.0 \\
\hline
\end{tabular}




\section{References}

(1) Wallenfels, K.; Friedrich, K., Über Fluorchinone, II. Zur Hydrolyse Und Alkoholyse Des Fluoranils. Chem. Ber. 1960, 93, (12), 3070-3082.

(2) Essers, M.; Haufe, G., Chemical Consequences of Fluorine Substitution. Part 4. DielsAlder Reactions of Fluorinated $p$-Benzoquinones with Dane's Diene. Synthesis of Fluorinated D-Homosteroids. J. Chem. Soc., Perkin Trans. 1 2002, (23), 2719-2728.

(3) Kingsbury, C. J.; Abrahams, B. F.; D’Alessandro, D. M.; Hudson, T. A.; Murase, R.; Robson, R.; White, K. F., Role of $\mathrm{NEt}_{4}{ }^{+}$in Orienting and Locking Together $\left[\mathrm{M}_{2} \mathrm{lig}_{3}\right]^{2-}(6,3)$ Sheets $\left(\mathrm{H}_{2}\right.$ lig $=$ Chloranilic or Fluoranilic Acid $)$ to Generate Spacious Channels Perpendicular to the Sheets. Cryst. Growth Des. 2017, 17, (4), 1465-1470.

(4) Spek, A. L., PLATON SQUEEZE: A Tool for the Calculation of the Disordered Solvent Contribution to the Calculated Structure Factors. Acta Crystallogr. C 2015, 71, (1), 9-18.

(5) Spek, A. L., Structure Validation in Chemical Crystallography. Acta Crystallogr. D 2009, 65, (2), 148-155.

(6) Aragao, D.; Aishima, J.; Cherukuvada, H.; Clarken, R.; Clift, M.; Cowieson, N. P.; Ericsson, D. J.; Gee, C. L.; Macedo, S.; Mudie, N.; Panjikar, S.; Price, J. R.; RiboldiTunnicliffe, A.; Rostan, R.; Williamson, R.; Caradoc-Davies, T. T., MX2: A High-Flux Undulator Microfocus Beamline Serving Both the Chemical and Macromolecular Crystallography Communities at the Australian Synchrotron. J. Synchrotron Rad. 2018, 25, (3), 885-891.

Kabsch, W., XDS. Acta Crystallogr. D 2010, 66, (2), 125-132.

(8) Alvarez, S., Distortion Pathways of Transition Metal Coordination Polyhedra Induced by Chelating Topology. Chem. Rev. 2015, 115, (24), 13447-13483.

(9) Llunell, M.; Casanova, D.; Cicera, J.; Alemany, P.; Alvarez, S., SHAPE, Version 2.1. ed.; Universitat de Barcelona: Barcelona, Spain, 2013.

(10) Bockman, T. M.; Kochi, J. K., Isolation and Oxidation-Reduction of Methylviologen Cation Radicals. Novel Disproportionation in Charge-Transfer Salts by X-ray Crystallography. J. Org. Chem. 1990, 55, (13), 4127-4135.

(11) Leblanc, N.; Mercier, N.; Toma, O.; Kassiba, A. H.; Zorina, L.; Auban-Senzier, P.; Pasquier, C., Unprecedented Stacking of $\mathrm{MV}^{2+}$ Dications and $\mathrm{MV}^{\bullet+}$ Radical Cations in the Mixed-Valence Viologen Salt $(\mathrm{MV})_{2}\left(\mathrm{BF}_{4}\right)_{3}(\mathrm{MV}=$ Methylviologen $)$. Chem. Commun. 2013, 49, (87), 10272-10274.

(12) Porter, W. W., III; Vaid, T. P., Isolation and Characterization of Phenyl Viologen as a Radical Cation and Neutral Molecule. J. Org. Chem. 2005, 70, (13), 5028-5035.

(13) Sutton, A. L.; Abrahams, B. F.; D'Alessandro, D. M.; Elliott, R. W.; Hudson, T. A.; Robson, R.; Usov, P. M., Structural and Optical Investigations of Charge Transfer Complexes Involving the F4TCNQ Dianion. CrystEngComm 2014, 16, (24), 5234-5243.

(14) Sutton, A. L.; Abrahams, B. F.; D'Alessandro, D. M.; Hudson, T. A.; Robson, R.; Usov, P. M., Structural and Optical Investigations of Charge Transfer Complexes Involving the Radical Anions of TCNQ and F4TCNQ. CrystEngComm 2016, 18, (46), 8906-8914. 
(15) Kistenmacher, T. J.; Emge, T. J.; Bloch, A. N.; Cowan, D. O., Structure of the Red, Semiconducting Form of 4,4',5,5'-Tetramethyl- $\Delta^{2,2}$-bi-1,3-diselenole-7,7,8,8-tetracyano- $p$ quinodimethane, TMTSF-TCNQ. Acta Crystallogr. B 1982, 38, (4), 1193-1199.

(16) Huang, F.; Switek, K. A.; Zakharov, L. N.; Fronczek, F. R.; Slebodnick, C.; Lam, M.; Golen, J. A.; Bryant, W. S.; Mason, P. E.; Rheingold, A. L.; Ashraf-Khorassani, M.; Gibson, H. W., Bis( $m$-phenylene)-32-Crown-10-Based Cryptands, Powerful Hosts for Paraquat Derivatives. J. Org. Chem. 2005, 70, (8), 3231-3241. 